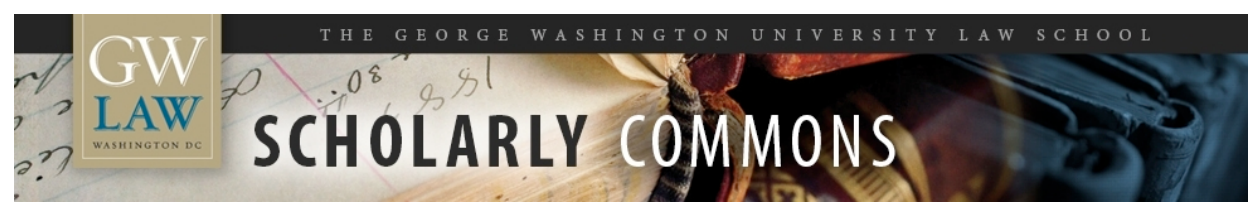

\title{
Musical Work Copyright for the Era of Digital Sound Technology: Looking Beyond Composition and Performance
}

Robert Brauneis

The George Washington University Law School, rbraun@law.gwu.edu

Follow this and additional works at: https://scholarship.law.gwu.edu/faculty_publications

Part of the Law Commons

\section{Recommended Citation}

Brauneis, Robert, Musical Work Copyright for the Era of Digital Sound Technology: Looking Beyond Composition and Performance (February 23, 2014).

This Article is brought to you for free and open access by the Faculty Scholarship at Scholarly Commons. It has been accepted for inclusion in GW Law Faculty Publications \& Other Works by an authorized administrator of Scholarly Commons. For more information, please contact spagel@law.gwu.edu. 


\section{MusicAl WORK COPYRIGHT FOR THE ERA OF DigITAL SOUND TECHNOLOGY: LOOKING BEYOND COMPOSITION AND PERFORMANCE}

\section{Robert Brauneis*}

For over 150 years, copyright law in the United States reflected and reinforced the model of music as a two-stage art of composition and performance. Composition - a deliberative activity that allowed rethinking and editing - produced a score, a stable, visually perceptible representation of melody, harmony and rhythm that used a system of mostly discrete notation. A score was realized in performance, a real-time, low-deliberation, no-editing activity that was evanescent, unrepeatable, purely aural, and continuous. Copyright law protected musical compositions embodied in scores. It did not protect performances.

Although some musical practices may never have fit this two-stage model, the model has faced new challenges from developments in sound technologies and their uses by musicians and listeners. In many genres of popular music, written notation is often no longer involved at any stage of producing a recording. Songs are assembled during days of experimentation in a rehearsal space or recording studio, and the roles of composer, musician and producer are blurred as composition, performance, recording,

* Professor of Law and Co-Director of the Intellectual Property Law Program, The George Washington University Law School; Member, Managing Board, Munich Intellectual Property Law Center; Abraham L. Kamenstein Scholar in Residence, United States Copyright Office, 2013-2014. For financial support to write this article, I would like to thank Deans Paul Schiff Berman and Gregory Maggs. For helpful comments, I would like to thank Jessica Litman and Peggy Radin and their students in their Spring 2012 intellectual property seminar at the University of Michigan Law School; Neil Netanel and David Nimmer and their students in the Fall 2012 UCLA Entertainment, Media \& IP Workshop; the participants in the 2012 Cyberlaw Colloquium at Harvard Law School, with special thanks to Jonathan Zittrain for hosting and Kendra Albert for taking notes; the participants in the 2012 Intellectual Property Scholars Conference at Stanford Law School; Pierre-Emanuel Moyse and the participants in the seminar at the Centre for Intellectual Property and Policy at McGill University; Irina Manta and the participants in the Hofstra University School of Law Intellectual Property Colloquium; Olufunmilayo Arewa; Charles Cronin; Kristelia Garcia; Jamie Lund; Sean O'Connor; Sean Pager; Pam Samuelson; Roger Schechter; and Rebecca Tushnet. I performed some research on copyright registrations presented in this article while I was the Kamenstein Scholar in Residence at the U.S. Copyright Office. For support in that position, I would like to thank the Register of Copyrights, Maria A. Pallante, and for assistance with that research, I would like to thank Alison Storella and Aaron Watson. All opinions expressed in this article are of course my own, and are not to be attributed to the Copyright Office or any other entity. 
synthesizing, sequencing, sampling, editing, processing, and mixing are accomplished iteratively and collaboratively. Thus, many songs are now first born as recordings, and notated versions of such songs are only approximations of the recorded works. That change in musical practice has been accompanied by changes in the use of the word "song" itself. While a turn-of-the-twentieth-century "song-plugger" was marketing sheet music, the "songs" sold on iTunes are digital files intended to be rendered by electronic devices as musical experiences.

Although the creation of virtually all commercially important music still involves some human performance activity, it also typically involves postperformance splicing, mixing, and direct electronic modification of sound - in effect, composition after performance, a reversal of the traditional order that potentially changes the meaning of both activities. In addition, it often incorporates synthesized, sequenced sounds that avoid human performance and capture of sound through transduction altogether. Thus, although we still speak of "recordings," with that term's connotation of a faithfully captured human performance, most currently produced, commercially important popular "recordings" are not viewed by either creators or consumers merely as "veridic" or "figurative" representations of performances that occurred at a particular time and place. Rather, they are aesthetic objects in their own right, and their creators employ and combine both performance and nonperformance techniques, in various degrees and at various points in the production process, to create them.

The nature of these aesthetic objects is affected by what varies, and what remains the same, when the media in which they are fixed are rendered as sound in different times and places. The musical experiences generated by digital files and sound equipment can be repeated with much less variation across many dimensions than musical experiences in the pre-sound-recording era. Hand a score to two professional musicians, and you will get performances that can differ markedly in tempo, articulation, timbres, and so on. Play a digital file on two reasonably good digital players with speakers or headphones, and the performances will differ in matters such as overall frequency response and reverberation, not in most of the details that would vary from musician to musician. As a result, recordings allow detailed sound textures to be finely sculpted and appreciated through successive nearidentical listening experiences.

While some musical practices thus changed greatly over the century after the invention of the phonograph in 1877, recognition of copyrightable subject matter under federal copyright law did not. That law continued to 
protect only musical scores, and thus ensured that musical composition, as the expression of music in scores, occupied a distinct and privileged place in the world of legally-protected music. Not until the 1970s did Congress take two legislative actions that cumulatively threw the significance of the score into doubt, and raised the issue of how to understand and define musical works embedded in sound recordings.

First, in the Sound Recording Act of $1971,{ }^{1}$ Congress extended federal copyright protection to a new type of creative work, the sound recording. However, the scope of protection for sound recordings was limited, and the creation of that limited protection left the distinction between musical composition and performance largely in place. Musical compositions still needed to be fixed in scores to gain copyright protection. Once fixed in scores, the 1909 Act granted them full reproduction, derivative work, and public performance rights, including rights against imitation. ${ }^{2}$ By contrast, musical sound recordings were conceptualized largely as captured performances, ${ }^{3}$ and received more limited protection in two respects. First, Congress limited the scope of reproduction and derivative work rights for sound recordings to what in the 1950s and 1960s was called "dubbing" ${ }^{4}$-mechanical or electronic reproduction that is the sonic equivalent of photocopying. Copyright protection for a sound recording thus "do[es] not extend to the making or duplication of another sound recording that consists entirely of an independent fixation of other sounds, even though such sounds imitate or simulate those in the copyrighted sound recording." Second, the Sound Recording Act of 1971 did not grant sound recordings a public performance right. Thus, whoever counted as an author of a musical work fixed in a score was entitled to receive income whenever that work was publicly performed;

\footnotetext{
${ }^{1}$ Sound Recording Act of 1971 \$ 1, Pub. L. No. 92-140, 85 Stat. 391 (1971).

${ }^{2}$ See 17 U.S.C. $\$ \$ 1(a), ~ l(b), ~ l(e) ~(1909)$.

${ }^{3}$ The Senate Report to the Sound Recording Act of 1971 does recognize that record producers, as well as performers, might be considered authors of sound recordings, but it still conceives of the capture of a performance in a recording session as a necessary and central act of producing a musical sound recording. Thus, it states that authorship might be recognized both "on the part of the performers whose performance is captured" and "on the part of the record producer responsible setting up the recording session, for capturing and electronically processing the sounds, and compiling and editing them to make the final sound recording." Creation of a Limited Copyright in Sound Recordings, S. Rep. No. 92-72, at 5 (April 20, 1971).

${ }^{4}$ See Barbara A. Ringer, The Unauthorized Duplication of Sound Recordings, Study No. 26, Studies Prepared for the Subcommittee on Patents, Trademarks, and Copyrights of the Committee of the Judiciary, United States Senate, $86^{\text {th }}$ Cong., $2 \mathrm{~d}$ Sess. (Comm. Print 1961) (study prepared February 1957).

${ }_{5}^{5}$ Sound Recording Act of 1971, supra note 1, \$ 1(a) (codified at 17 U.S.C. \$ 1(f) (1909)).
} 
whoever counted only as an author of a sound recording fixed in a phonorecord was not.

Five years later, the Copyright Act of 1976 worked a potentially much more fundamental change in the conceptualization and protection of musical compositions, which it renamed "musical works." In the 1976 Act, Congress discarded the requirement that musical works be fixed in scores, and instead provided that musical works could gain copyright protection even if fixed only in phonorecords - that is to say, fixed as sounds in media like magnetic tapes, hard drives, optical discs, and silicon chips. Moreover, Congress apparently discarded the musical score requirement retroactively, thereby granting copyright protection to many musical works fixed in phonorecords but not in scores before the effective dates of either the 1976 Act or the Sound Recording Act of $1971 .^{6}$

The addition of phonorecords as a means for fixing musical works was undoubtedly motivated by the reality that commercial production of music no longer necessarily involved scores. However, such an addition also arguably recognizes that a phonorecord-embodied musical work is an aesthetic object of a different kind, with different properties, than a notated musical work. While notated musical works require human performances for realization, phonorecord-embodied musical works, which might also be called "musical audio works," do not require such performances, and hence the composition/performance distinction must apply to them differently, if at all. Either the entire repeatable listening experience that can be rendered from the phonorecord should be recognized as "composition," and the rendering by an electronic or mechanical device should be treated as "performance." or we should recognize that, with the 1976 Act change from "musical composition" to "musical work," the composition/performance distinction may not be applicable some musical works at all. Of course, some musical audio works may still be adaptations of notated musical works, but that does not mean that every musical audio work is necessarily divided into "composition" and "performance" elements, any more than a motion picture, which may be an adaptation of a novel, is necessarily divided into literary-work and nonliterary-work elements.

As a proposed interpretation of the 1976 Act, such a view faces a major hurdle. While the 1976 Act newly recognizes the existence of phonorecordembodied musical works, it also retains the scheme established in the Sound Recording Act of 1971, under which musical works receive full copyright

${ }^{6}$ See infra n. 96. 
protection, while sound recordings receive reproduction and derivative work rights that are limited to "dubbing," and no public performance rights at all. ${ }^{7}$ If a phonorecord-embodied musical work encompasses the entire repeatable listening experience that can be rendered from the phonorecord, then the musical work fixed in the phonorecord is coextensive with the sound recording fixed in that phonorecord. That effectively extends rights against imitation and public performance rights to the entirety of some sound recordings, which is in significant tension with the provisions denying sound recordings such rights.

Yet an approach that seeks to maintain a composition/performance distinction within phonorecord-embodied musical works, by separating "composition elements" from "performance elements" within those works, also faces major difficulties. Given the history of music copyright, one might most naturally look to a score to guide the identification of compositional elements within a phonorecord-embodied musical work. In many cases, however, there will be no score available, and even if there is, it is no longer clear that a score should be determinative.

In the face of these difficulties, this article will argue that the better course is to cease trying to divide musical sound recordings into composition and performance elements. It will make the case that the 1976 Act could be interpreted to require abolition of such a distinction, but it will also argue that the Act should be amended if necessary. An approach that recognizes that phonorecord-embodied musical works are distinct from notated musical works, and are protectable on their own terms, can potentially better serve the purposes of copyright law in at least three ways. First, such an approach would be more consistent with the basic understanding that substantial similarity in music is to be evaluated through the comparative aesthetic appeal of listening experiences. Second, it would help to enable creators of all aspects of those listening experiences to enjoy the incentives and benefits of authorship. Third, it could be a step towards recognition of unitary copyright in some musical audio works.

The Article proceeds in five Parts. Part I describes the musical work, both in practice and in law, before the age of fixed sound, when written notation was central. Part II describes the change in practice wrought by developments in sound recording technology, and the birth of a new type of

\footnotetext{
${ }^{7}$ Congress has in the meantime granted sound recordings a limited "digital audio transmission right," see 17 U.S.C. $\$ 106(6)$, but that right is still significantly narrower than the public performance right granted to musical works.
} 
aesthetic object, the musical audio work. Through a study of copyright registrations, Part III shows how the role of musical notation in creating musical works has waned over the last 35 years. Part IV critically analyzes the current legal treatment of musical works embedded in phonorecords, and the continued attempts to separate composition elements from performance elements. Part V considers the benefits, drawbacks, and collateral consequences of recognizing phonorecord-embodied musical works as coextensive with sound recordings. Part VI provides some brief concluding remarks.

\section{The Musical Work in Practice ANd LAW IN THE AGE OF THE WRITTEN SCORE}

Throughout history, plenty of music has been made and transmitted from generation to generation without written scores. Musicians working within what might be called folk traditions learn music by listening to performances and imitating them, often repeatedly with the guidance and corrections of a formal or informal teacher, until they have them more-or-less fixed in memory. At another extreme, mechanical musical devices, such as music boxes, musical clocks, and mechanical organs, have existed for centuries. Such musical automata make music without any human performance at all, and the musical patterns are fixed, not in written notation or human memory, but in physical arrangements such as pins placed on a barrel or perforations made on a disc. ${ }^{8}$

During the nineteenth century and into the early decades of the twentieth century, however, the dominant model of musical practice cast music as a two-stage art, ${ }^{9}$ necessarily comprised of two fundamentally different activities: composition and performance. Composition was a deliberative activity that allowed rethinking and editing. Its end product was a written score, ${ }^{10}$ a stable, visually perceptible set of prescriptions for musicians to follow. Scores virtually universally used a system of notation -

${ }^{8}$ Even prominent composers such as Wolfgang Amadeus Mozart and Joseph Haydn wrote pieces intended for mechanical instruments. See Alfred Chapuis, The History of the Musical Box and of Mechanical Music 59-65 (Joseph E. Roesch, translator 1980).

${ }^{9}$ I have borrowed the phrase "two-stage art" from Nelson Goodman, Languages of Art 114 (1968).

${ }^{10}$ I use "score" here in its broad musical sense, referring to "a page, volume, fascicle or other artefact containing a complete copy of a musical work." David Charlton \& Kathryn Whitney, "Score," Grove Music Online. In a narrower sense, a "score" is a document in which the music for all instruments and voices in a composition is presented together, whereas "parts" are documents in which the music for each instrument or voice is presented separately. See id. 
Western staff or stave notation - which is mainly discrete: composers choose between an F and an F sharp, or between a quarter note and an eighth note, instead of setting pitches or durations along a continuum. ${ }^{\text {ll }}$ However, staff notation typically indicates relative rather than absolute pitch and duration, and also gives inexact cues about matters such as dynamics (loudness), articulation (legato and staccato rendering of note sequences), timbre, and so on. Thus, it leaves room for - and requires - interpretive choices in performance.

Performance contrasts with composition in many respects. While a score is stable and visually perceptible, performance is unrepeatable, evanescent, and aural. While composition is a deliberative process that allows for trial-and-error editing, performance is a real-time, low-deliberation, noediting activity.

An investigation into the reasons for the emergence of this composition/performance model in musical practice and in law is far beyond the scope of this paper, but a few tentative observations may be helpful. Musical historians Lydia Goehr and Joseph Kerman, among others, have argued that in the nineteenth century, musical practice centered increasingly on the concept of the "musical work." 12 In earlier eras, pieces of music were more likely to be understood as a part of an event like a church service, as a method for presenting a text, or as an act of performance. Following this earlier understanding, Georg Friedrich Händel's "Music for the Royal Fireworks," for example, would be viewed as analogous to the fireworks show that it accompanied on April 27, 1749. ${ }^{13}$ Both the music and the fireworks were planned, and even embodied in a written set of instructions, and the designers of both had prominent reputations in their times (the fireworks were designed by one Thomas Desguliers). ${ }^{14}$ Yet both were also constructed of elements that could be and were recombined and rearranged to suit various occasions, and there was no more thought of cataloguing the music performed

${ }^{11}$ For one introduction to musical notation, see Stan Hawkins and John Shepherd, "Notation," in II Continuum Encyclopedia of Popular Music of the World 254 (John Shepherd et al., eds., 2003).

${ }^{12}$ See Lydia Goehr, The Imaginary Museum of Musical Works: An Essay in the Philosophy of Music 176-242 (2007); Joseph Kerman, Contemplating Music: Challenges to Musicology

13 See Wikipedia, "Music for the Royal Fireworks," http://en.wikipedia.org/wiki/Music_for_the_Royal_Fireworks .

${ }^{14}$ See id. 
that day in a Händel-Werke-Verzeichnis ${ }^{15}$ than there is today in cataloguing the fireworks in a Desguliers-Werke-Verzeichnis.

By contrast, a "work" of music is an autonomous, enduring artistic creation that could potentially be deemed a masterpiece and have a place in a timeless canon of such works. Lawrence W. Levine and Olufunmilayo Arewa have described the work as arising from a process of "sacralization," of "endow[ing] the music it focused upon with unique aesthetic and spiritual properties that rendered it inviolate, exclusive, and eternal."16 The notion of an artistic canon, and the related awareness of history, had arisen earlier in literature and in the visual arts, and the emerging concept of musical work borrowed from literary and artistic criticism.

If the rise of the composition/performance model can be linked to lofty notions of timeless canons of masterpieces, however, it can also be linked to somewhat more earthbound realities of economics, technology, and society. ${ }^{17}$ As printing costs dropped and pianos proliferated in upper-middle class parlors around the country, printed musical scores began to play an important and profitable role in the dissemination of music into millions of homes. While some of those scores came from the European classical tradition, the biggest sellers were sheet music of popular songs, in simple arrangements that could be performed by a single amateur pianist-vocalist. Most of the music copyright litigation through the middle of the twentieth century was about such popular sheet music, and it is fair to say that the conception of music copyright held by several generations of judges was influenced by sheet music of that type.

The emphasis on the score as musical work directed the attention of musicians and listeners towards the elements of music that are most easily expressed in Western musical notation. That notation has tended to channel music into the twelve tones that it expresses in its basic form, and to focus

${ }^{15}$ A catalogue of Händel's works, published between 1978 and 1986, modeled on earlier catalogues of the works of other composers, such as the Köchel-Verzeichnis of Mozart's works, completed in 1862. See see Wikipedia, "Händel-Werke-Verzeichnis," http://en.wikipedia.org/wiki/HWV; Wikipedia, "Köchel catalogue," http://en.wikipedia.org/wiki/K\%C3\%B6chel_catalogue.

${ }^{16}$ See Lawrence W. Levine, High Brow, Low Brow: The Emergence of Cultural Hierarchy in America 101 (1988); Olufunmilayo Arewa, Writing Rights: Copyright's Visual Bias and African American Music, at 34-38 (available at http://ssrn.com/abstract=2010024 )

${ }^{17}$ Another article taking the view that the concept of musical work was influenced both by aesthetics and the market in sheet music is Jason Toynbee, Copyright, the work, and phonographic orality in music, 15 Social and Legal Studies 77, 80-82 (2006). 
attention on certain structural aspects of music, such as melody and harmony. Those discrete tones and structural aspects were given primary status in composition, while other aspects of music were largely relegated to the realm of the performer, or neglected altogether. Thus, as Michael Chanan has written:

Western notation deals poorly with certain aspects of musical expression, like dynamics, attack, and timbre, which cannot be calculated in the same way and given fixed values: their values are relative. At best, therefore, they are indicated by means of codes written alongside the stave, which are necessarily approximate and suggestive, rather than precise and prescriptive. They do not disappear from performance, of course, but notation demotes them, they cease to carry any structural significance, and in some cases they are even repressed. ${ }^{18}$

The emphasis on rough, basic relationships of pitch and timing in a memorable sequence of notes - that is to say, on melody - can also be appreciated from the perspective of listeners. Up through the early age of sound recordings, people were used to hearing a song performed by many different performers, in many different circumstances. As Elijah Wald puts it, what became popular for a few months in the late 1800s and early 1900s was not a particular recording, but a song, and the average member of the public would hear that song, "at concerts, in vaudeville shoes, on street corners, at restaurants, in saloons, or at home around the piano," ${ }^{19}$ as well as, in the early days of sound recordings, on various scratchy recordings by different

${ }^{18}$ Michael Chanan, Musica Practica 5-6 (1994); see Michael Chanan, Repeated Takes: A Short History of Recording and its Effects on Music 10-1l (1995) (describing the same phenomenon). Others who have observed the relationship between musical notation and an emphasis on certain elements of music include Olufunmilayo Arewa, Paul Théberge, and David Brackett. See Olufunmilayo Arewa, From J.C. Bach to Hip Hop: Musical Borrowing, Copyright and Cultural Context, 84 N.C. L. Rev. 547, 564 , 625-26 (2006); Paul Théberge, Technology, Creative Practice and Copyright, in Music and Copyright (Simon Frith \& Lee Marshall eds. 2nd ed. 2004); David Brackett, "Music," in Key Terms in Popular Music and Culture 124, 126 (Bruce Horner \& Thomas Swiss, eds., 1999).

${ }^{19}$ Elijah Wald, How the Beatles Destroyed Rock 'n' Roll: An Alternative History of American Popular Music 87 (2009); see Daniela Furini, "From recording performances to performing recordings: Recording technology and shifting ideologies of authorship in popular music," TRANS - Transcultural Music Review 14 (Article 10) (2010), http://www.sibetrans.com/trans/all/from-recording-performances-to-performingrecordings-recording-technology-and-shifting-ideologies-of-authorship-in-popularmusic. 
performers. For the most part, what those performances had in common were the elements represented in standard musical notation - the song's melody and words - and thus a listener might naturally focus her attention and appreciation on those elements. ${ }^{20}$

B. The Development of Copyright in Music from 1831 to the 1970s: the Written Score and "the Essence of Musical Creation"

The history of musical copyright in the United States from the first explicit acknowledgement of "musical compositions" in 1831 until the changes wrought by the Sound Recording Act of $1971^{21}$ and the Copyright Act of $1976^{22}$ reveals two major themes. First, the musical composition, or musical work, was associated very closely with the written score, so much so that for many purposes, one could assume that the two were related definitionally - that musical works were works created in the language of musical notation, just as literary works are works created in written language. At the same time, however, when beginning to consider state-law protection for musical works embedded in sound recordings, some courts took an even more restrictive view, excluding some elements that are subject to musical notation and focusing on basic melodic and harmonic structures.

\section{Federal Copyright and the Musical Work as Score}

In 1831, Congress first recognized "musical compositions" as a separate category of copyrightable subject matter under federal law. ${ }^{23}$ Although case law had previously established that scores might be federally protected as "books," 24 the recognition of musical compositions as distinct

${ }^{20}$ In the early era of sound recordings, when amateur musical performance was still much more common, a listener's goal in listening to a sound recording might have been to learn the song in order to perform it herself, rather than to appreciate it as an aesthetic object. If that was the goal, then she might have approached the record instrumentally, as we approach language instruction recordings today. We are not very picky about who is performing on those language instruction recordings, and we may not concentrate on the peculiarities of the performer's voice, because our goal is to speak the language ourselves, not to listen to the recordings for aesthetic pleasure.

${ }^{21}$ Pub. L. No. 92-140, 85 Stat. 391 (Oct. 15, 1971).

${ }^{22}$ Pub. L. No. 94-553, 90 Stat. 2541 (Oct. 19, 1976).

${ }^{23}$ Act of Feb. 3, 1831, \$ 1, 4 Stat. 436.

${ }^{24}$ Even before the Copyright Act of 1790 was passed, the Court of King's Bench had decided that copyright under the Statute of Anne, the direct model for the 1790 Act, extended to musical scores. See Bach v. Longman, 98 Eng. Rep. 1274 (K.B. 1777). Composers registered a variety of musical compositions under the 1790 Act, apparently beginning on Februrary 22, 1792 with the registration of "An anthem designed for Thanksgiving day - but proper for any publick occasion," written by one 
objects of copyright protection lent weight to the notion that notated musical works were central to the practice of music. Interestingly, when adding protection for music, Congress chose to use more abstract language than it ever had previously to describe copyrightable subject matter. Books, maps, charts, and engravings, the objects of federal copyright protection before 1831, can all be seen as physical things - copies - rather than, or as well as, intangible creations - works. By contrast, a "musical composition" is a wholly intangible object, separate from its embodiment in a musical score.

Whether the concept of musical composition in copyright law was the same as, and stemmed from, the concept of musical work in nineteenthcentury aesthetics - the work as autonomous, enduring artistic creation - is a matter of some disagreement between scholars. Lydia Goehr assumes that the legal concept sprang from the aesthetic concept, ${ }^{25}$ and Jason Toynbee, while recognizing material and technological as well as aesthetic determinants of the concept, also contends that it was formed outside the law and then assimilated into it. ${ }^{26}$ By contrast, Anne Barron argues that the legal concept of musical work emerged before the aesthetic concept, out of common-law property reasoning, and in particular out of a shift from physicalism to formalism in that reasoning; the legal concept, she argues, is at least partially independent of the aesthetic concept and has a different focus. ${ }^{27}$

If "musical composition" is an abstract concept, however, there is no doubt that copyright law and practice identified the musical composition with the printed musical score. From 1790 through 1977, federal copyright protection for musical compositions could be obtained only through fixation

William Cooper. See Federal Copyright Records 1790-1800, 77 (1987). In 1829, U.S. Supreme Court Justice Smith Thompson, riding circuit and looking to English law as a source for American law, declared that "[i]t seems to be well settled in England, that a literary production, to be entitled to the protection of the statute on copyrights ... may be printed on one sheet, as the words of a song or the music accompanying it." Clayton v. Stone, 5 F. Cas. 999, 1000-01 (Cir. Ct. S.D.N.Y. 1829). On the development of copyright protection for music in England, see Michael Carroll, The Struggle for Music Copyright, 57 Fla. L. Rev. 907 (2005); Nancy A. Mace, Litigating the Musical Magazine: The Definition of British Music Copyright in the 1780s, 2 Book History 122 (1999).

${ }^{25}$ Lydia Goehr, The Imaginary Museum of Musical Works: An Essay in the Philosophy of Music 218-219 (2007).

${ }^{26}$ See Jason Toynbee, Copyright, the work, and phonographic orality in music, 15 Social and Legal Studies 77 (2006).

${ }^{27}$ See Anne Barron, Introduction: Harmony or Dissonance? Copyright Concepts and Musical Practice, 15 Social \& Legal Studies 25, 46-47 (2006); Anne Barron, Copyright Law's Musical Work, 15 Social \& Legal Studies 101, 118-122 (2006). 
in, and publication of, musical scores. The deposit of musical scores with the government, a requirement of copyright protection until 1909, continued to be a requirement of filing infringement suits until 1978.

Although mechanical reproduction of music gained increased significance in the late nineteenth century, several federal court decisions, culminating in the Supreme Court decision in White-Smith Music Publishing Co. v. Apollo Company ${ }^{28}$ in 1908, reaffirmed the centrality of the score. Those decisions all concerned the question of whether mechanical devices that made music could infringe copyright in musical compositions. In answering that question in the negative, however, the decisions took for granted, and reinforced, the principle that copyright protection would only be granted to musical compositions on the basis of their embodiment in scores, not in mechanical devices. Moreover, the score was understood to be defined by its role in the "two-stage art" model of musical practice. Scores had to be readable by musicians, because human performances were considered to be the integral second stage of the production of music. Perforated rolls did not count as scores because they were "not intended to be read as an ordinary piece of sheet music, which, to those skilled in the art, conveys, by reading, in playing or singing, definite impressions of the melody." ${ }^{29}$ Thus under the rule of WhiteSmith, scores capable of being read by musicians were necessary both for the protection of musical compositions, and for the infringement of the reproduction and distribution rights in those compositions.

With regard to infringement, the Copyright Act of 1909 overturned the White-Smith holding by granting the owners of copyright in musical compositions a right to royalties from mechanical equipment that could produce performances of those works. ${ }^{30}$ However, under the 1909 Act, one could still only obtain federal copyright protection of a musical composition by publication of visually perceptible copies of that composition with proper copyright notice, or in the case of unpublished works, by registration accompanied by deposit of a visually perceptible copy. ${ }^{31}$ The public

${ }^{28} 209$ U.S. 1 (1908). Earlier lower court cases included Kennedy v. McTammany, 33 Fed. 584 (D. Mass. 1888) (piano rolls), and Stern v. Rosey, 17 App. D. C. 562 (1901) (phonograph cylinders).

${ }^{29}$ White-Smith, 209 U.S. at 18.

${ }^{30}$ See 17 U.S.C. $\$ 1($ e) (1909 Act). The 1909 Act also protected dramatic compositions against mechanical devices that could render performances.

${ }^{31}$ As for unpublished works, the Copyright Act of 1909 provided that "Copyright may also be had of the works of an author of which copies are not reproduced for sale, by the deposit, with claim of copyright, of one complete copy of such work if it be a ... musical composition ...." Act of March 4, 1909, \$ 11 . As for published works, there 
distribution of phonograph records embodying a performance of a musical composition could not result in the acquisition of federal copyright in that composition, even if the records displayed copyright notice for the musical composition. $^{32}$

Further reinforcing the identification of musical composition with score, the Copyright Office registered musical compositions only on the basis of the deposit of written scores. As the 1970 Compendium of Copyright Office Practices put it, "[a] sound recording of a musical composition is not acceptable for registration in Class E [covering musical compositions]. When a sound recording is deposited, the Office will reject the claim but point out to the applicant the possibility of writing out the composition in manuscript form and then making registration on the basis of the manuscript." ${ }^{33}$ Such a

appear to be no cases holding squarely that visually perceptible copies were required, but there are certainly no cases granting relief to authors of musical works that were not fixed in such copies, and the commentators seem to agree unanimously that visually perceptible copies were necessary to obtain federal copyright. See 1 Melville B. Nimmer \& David Nimmer, Nimmer on Copyright $\$ 4.05$ [B][1] ("[S]ale of records did not divest statutory rights in the recorded work if prior to public distribution of the records, a statutory copyright had been obtained either by publishing printed copies of the work bearing a proper copyright notice, or by depositing an unpublished manuscript of the work in the Copyright Office.") (emphasis added); Benjamin Kaplan, Publication in Copyright Law: The Question of Phonograph Records, 103 U. Pa. L. Rev. 469, 482-83 (1955) (" $[\mathrm{I}] \mathrm{t}$ is very doubtful whether the Code admits of obtaining copyright through the medium of a phonograph record as distinguished from a paper with notations.... A labored argument can be made against the grain of the statute for accepting records for this purpose.").

${ }^{32}$ Thus, public distribution of what we now call phonorecords could not count as an "investive publication" of a musical composition, resulting in the acquisition of federal copyright. Could it count as a "divestive publication," resulting in the forfeiture of federal copyright? Inconsistent court rulings on that issue persisted into the 1990s, until Congress amended the Copyright Act in 1997 to provide that distribution of phonorecords under the 1909 Act would never count as publication, investive or divestive, of a musical composition. See "An Act to make technical amendments to certain provisions of Title 17, United States Code," Act of Nov. 13, 1997, Pub. L. 105-80, $\$ 11$, 111 Stat. 1529, codified at 17 U.S.C. $\$$ 303(b) (providing that "[t] he distribution before January 1, 1978, of a phonorecord shall not for any purpose constitute a publication of the musical work embodied therein"); ABKCO Music, Inc. v. LaVere, 217 F.3d $684\left(9^{\text {th }}\right.$ Cir. 2000) (holding that Congress intended the amendment to be retroactively applied to a case in which the District Court had decided before enactment of the amendment that distribution of a phonorecord had published the underlying musical work).

${ }^{33}$ U.S. Copyright Office, Compendium of Copyright Office Practices (As of July l, 1970) (hereinafter "Compendium I") 2.6.2 II. "Sound Recordings Not Acceptable," at p. 2-33. See U.S. Copyright Office, Compendium of Copyright Office Practices (1984) 
manuscript did not need to "employ the conventional form of music notation," but it did need to be "intelligible and capable of being read and visually perceived." 34 This was because to be counted as a "musical composition," a "work must generally contain notations representing a succession of musical sounds, usually in some definite melodic and rhythmic pattern." 35 Because an owner of copyright in a work had to register and deposit copies of the work before filing an infringement suit, ${ }^{36}$ in every infringement suit the plaintiff's musical composition was represented by a notated, visually perceptible manuscript.

\section{Melody, Harmony, Rhythm and "the Essence of Musical Creation"}

The identification of musical work with written score, and with Western staff notation in particular, might focus attention on some elements of music, and hinder consideration of others. In practice, Western staff notation is not a closed, narrow set of symbols limited to the designation of pitches and durations, but a richer set of symbols that composers supplement as they see fit with words and newly defined symbols, which can express instructions concerning such matters as dynamics, articulation, tone color, and microtonal variation. ${ }^{37}$ However, some language in cases decided under the Copyright Act of 1909 or under state common law seems to express a more restrictive view of what count as elements of a musical work.

Part of the explanation is likely that almost all of the music infringement cases handled by courts in the era of the 1909 Act written

(known as "Compendium II") $\$$ 405.01(a) ("Copies required before 1978. Until 1978, a copy was the only form in which a musical work could be accepted for registration.); Edward A. Sargoy, UCC Protection in the United States: The Coming into Effect of the Universal Copyright Convention, 33 N.Y.U. 811, 850 n. 50 (1958) ("It has been the accepted practice in the Copyright Office, and in the profession, since the present law was enacted in 1909, not to register claims to copyright under Title 17 in works in exclusively acoustic form (either as to intellectual content, or rendition); Testimony of Edward P. Murphy, Subcommittee on Courts and Intellectual Property of the House Judiciary Committee, Hearings on Pre-1978 Distribution of Recordings Containing Musical Compositions; Copyright Term Extension; and Copyright Per Program Licenses, Serial No. 39, at 19 (June 27, 1997).

${ }^{34}$ Compendium I, supra n. 8, 2.6.2 I. "Conventional notation not necessary," at p. 2-32.

${ }^{35}$ Compendium I, supra n. 8, 2.6.1. "What are musical compositions." I. "Generally," at p. $2-23$.

36 See 17 U.S.C. \$ 13 (1909) ("No action or proceeding shall be maintained for infringement of copyright in any work until the provisions of this title with respect to the deposit of copies and registration of such work shall have been complied with.").

${ }^{37}$ For examples of notation concerning timbre, see note $\mathrm{xx}$ infra; for examples of notation of microtones, see note xx infra. 
notation requirement concern popular songs that were notated in the form of sheet music arranged sparsely for piano and voice. In the 1924 case of Fred Fisher, Inc. v. Dillingham, ${ }^{38}$ for example, the two works at issue, the plaintiffs' "Dardanella" and the defendant's "Ka-Lu-A," had both been published in such arrangements, and the allegedly infringed and infringing portions of those works were both left-hand piano figures written in the bass clef, in the key of C major, in 2/2 time, repeating once per measure. In such cases, there was little complexity to discuss. Once music began to be marketed through records, record companies began to obtain federal copyright protection by registering compositions as unpublished works in even simpler form, as lead sheets that contained only a melodic line. For example, in the 1952 case of Northern Music Corp. v. King Record Distributing Co., ${ }^{39}$ the court notes that " $[\mathrm{t}]$ he copyrighted sheet [of the plaintiff's musical composition, a song called 'Tonight He Sailed Again,' registered in 1944,] indicated only the melodic line; the published copy issued in early 1948 indicated the harmony." ${ }^{40}$ When the compositions at issue in the cases were as thin as that, courts had no occasion to dwell on matters other than rhythm, harmony, and melody, because the notations contained little or nothing else. Thus, in many of the cases in which courts articulated a definition of musical works in terms of a finite list of elements, they were not rejecting other elements proposed by one of the parties; rather, they were simply articulating what they were used to seeing in thinly notated sheet music or lead sheets.

That explanation is not complete, however, because at least one key decision appears to consider and reject other elements. That decision, issued in 1950 by the U.S. District Court for the Southern District of California in Supreme Records v. Decca Records, ${ }^{41}$ concerns the tangled issue of common-law copyright in musical elements or features that appeared in the plaintiff's sound recording but did not form part of a federally copyrighted notated composition, foreshadowing similar issues that would later arise under the Copyright Act of 1976. In the legislative history of the Sound Recording Act of 1971 and the Copyright Act of 1976, Supreme Records is referred to as the "socalled 'mirror recording' case, ${ }^{42}$ and is characterized as precedent for the lack

\footnotetext{
${ }^{38} 298$ F. 145 (S.D.N.Y. 1924)

${ }^{39} 105$ F.Supp. 393 (S.D.N.Y. 1952).

${ }^{40}$ Id. at 396.

${ }^{41} 90$ F. Supp. 904 (S.D. Cal. 1950).

${ }^{42}$ See Copyright Law Revision Part III, page 196 (comments of Sydney A. Diamond, London Records) (meeting of April 1l, 1963); see also id. at 75 (referring to "mirror copying") (comments of Leon Kellman, American Guild of Authors and Composers).
} 
of protection for sound recordings against independently fixed imitations, now codified in $\$ 114$ (b) of the Copyright Act.

In dicta, at least, the Supreme Records opinion is not quite so categorical. It also speculates that an unnotated musical arrangement might be protected against misappropriation, if it rose to the level of "musical creation":

Assuming that a common-law property right may be asserted to the arrangement in a recorded song, distinct from the right to the song itself, in order that a particular arrangement be given recognition as such, the elements which the recorder has introduced must involve creative ability of a distinct kind. Adding certain incidents, such as emphasis upon accent, which is all that the clapping does, does nothing to the essence of musical creation. Musical creation consists in the grouping of notes, similarity of bars, harmony or melody. . . Accent is important. But accent alone does not rise to the dignity of creation. ${ }^{43}$

It is a little difficult to know how to approach this passage, particularly because although the court mentions clapping and accent as if they were the only elements at issue in the case, the court actually rejects the plaintiff's claims concerning many more copied elements, including the addition of a group of male singers singing lyrics and a melody that did not appear in the copyrighted sheet music. ${ }^{44}$ One interpretation of the passage, however, is that "accent" simply forms no part of the copyrightable content of music. This interpretation recalls the notorious statement, appearing two years later in the Northern Music Corp. case, that rhythm and harmony are uncopyrightable, leaving only melody as the basis for musical copyright:

There is only a limited amount of tempos; these appear to have been long since exhausted; originality of rhythm is a rarity, if not an impossibility. Harmony is the blending of tones; this is achieved according to rules which have been known for many years. Being in the public domain for so long neither rhythm nor harmony can in itself be the subject of copyright. . . It is in the melody of the composition-or the arrangement of notes or tones that originality must be found. ${ }^{45}$

\footnotetext{
${ }^{43}$ Id. at $912-913$.

${ }^{44}$ For more detail on the Supreme Records case, see the online note at http://docs.law.gwu.edu/facweb/rbrauneis/musicalworkcopyright/supremerecords.ht m.

${ }^{45}$ Northern Music Corp., 105 F.Supp. at 400. For another view from the 1950s that is somewhat similar in nature but takes the opposite position, see Paul W. Orth, The
} 
The Northern Music Corp. statement has been roundly criticized by commentators $^{46}$ and has not been followed in subsequent cases. The Supreme Records statement about accent, interpreted as a categorical rejection of it forming any part of a copyrightable musical work, likely deserves the same fate. Both statements fail to recognize that copyright protects a musical work as a whole - as a complex assemblage of many individual elements - and that the choice to combine a particular rhythm with melodies, harmonies, and the like can render the rhythm an element of the protected work, even if the composer copied the rhythm from another source. ${ }^{47}$ This insight is of course not limited to music, but is equally applicable to all types of copyrighted works. $^{48}$

As a matter of history, however, Supreme Records and Northern Music Corp. do have their place. During the era that federal copyright required fixation of musical works in written notation, the legal concept of the musical work was certainly limited to the elements represented in that notation, and excluded elements that were added in performance. In addition, in some cases, it was even more narrowly conceived to exclude elements thought to be common and limited in number, or incidental or characteristically left to the discretion of performers.

\section{From the SOUnd ReCORding TO THE MusicAl Audio Work: NEW TECHNOLOGY AND NEW ART}

Use of Experts in Musical Infringement Cases, 16 U. Pitt. L. Rev. 232, 234 (1955) ("Since most if not all melodies hark back to old times, serious composers strike out in fields of harmony or rhythm (or lack of it).").

${ }^{46}$ See, e.g. Aaron Keyt, An Improved Framework for Music Plagiarism Litigation, 76 Cal. L. Rev. 421, 431 (1988) (characterizing the quotation as "unfortunately, not atypical of the way judges write about music").

${ }^{47}$ The Northern Music Co. statement suffers from other defects as well. It appears to adopt a patent-like view of originality, which would deny protection to any feature that could be found in the prior art of music, whether or not the plaintiff was aware of its prior appearance and copied or not. That view conflicts with established copyright doctrine. It also conflates tempo with rhythm, though they are in music theory two different things.

${ }^{48}$ See, e.g., Boisson v. Banian, Ltd., 273 F.3d 262, 272 (2d Cir. 2001) ("In applying this [more discerning ordinary observer] test, a court is not to dissect the works at issue into separate components and compare only the copyrightable elements... [That] would result in almost nothing being copyrightable because original works broken down into their composite parts would usually be little more than basic unprotectible elements like letters, colors and symbols."). 
We now turn to the developments in audio technology that began with wax cylinders and have led to sophisticated digital audio production software. This Part will seek to emphasize four points related to those developments. First, the development of equipment that is able to repeatedly render fine-grained, high-quality audio can be correlated with a shift in creative emphasis in a variety of musical genres. Much music that is created with audio playback in mind places less emphasis on the formal structures and scale-ordered pitches of written notation, and more emphasis on details like tone color, spatial effects, and microtones that fall in between the notes of a musical scale. Second, the enduring fascination with the apparent ability to transcend the flow of time by capturing and replaying fleeting audio reality has masked the fact that the "sound recordings" that currently constitute the bulk of popular music production are carefully constructed fictional audio experiences rather than faithfully captured performances. Third, "songs" are now often produced without the use of musical notation in layers of human performance, alteration and combination of such performances, and programming of sequenced sounds that avoid human performance altogether, and in collaborations that blur traditional roles of composer, performer, producer, and engineer. Statistical analysis of copyright registrations at the U.S. Copyright Office demonstrates that creators of music have decisively moved away from notation, and towards simultaneous registration of a "musical work" and a "sound recording" on the basis of a single phonorecord deposit.

\section{A. Repeatability, Manipulability, and the Appreciation of Sonic Detail}

In his book Capturing Sound, ${ }^{49}$ Mark Katz has explored the variety of reactions to the repeatability of sonic experience in great detail. This Part will focus on only one of those reactions. Katz begins by asking the reader to engage in a simple experiment:

Sing a single note. Now try to recreate that sound exactly-not simply its pitch, but its precise volume, length, intensity, timbre, attack, and decay. Now imagine trying to repeat an entire song in this way, down to the smallest detail. It simply cannot be done. ${ }^{50}$

Yet what cannot be accomplished by human performers can, with a much greater degree of accuracy and with much greater detail, be accomplished by sound technologies developed over the last century-and-a-half. Such

${ }^{49}$ Mark Katz, Capturing Sound: How Technology Has Changed Music (rev. ed. 2010).

${ }^{50}$ Id. at 29. 
technologies have enabled the production of repeatable listening experiences, and advances in those technologies have made possible ever more detailed and nuanced repeatable sound experiences, created through precise manipulation of sonic details. To be sure, a recording played over an AM car radio does not sound "the same" as that recording played on high-end equipment in a studio. But even those two different renderings preserve many details that would not be preserved in two live performances by the same performer, let alone by two different performers.

Such repeatability enables the appreciation of sonic nuances that are difficult to appreciate with a single hearing. The ability to manipulate and adjust such nuances, and to compare and contrast slightly different versions before selecting one, enables creative focus on those details in a way that live performance does not. To say that the development of sound technologies has therefore caused a change in the musical elements emphasized in some musical genres would be to commit to a debatable technological determinism. Without making such a commitment, however, we can trace a correlation between sound technologies and a shift in creative emphasis in the genres that form the bulk of commercially distributed music. As Theodore Gracyk has argued,

[A]pprehension of formal composition is hardly the primary attraction when listening and relistening to most rock music. Most of the rock audience shuns compositional complexity, either horizontally or vertically. In terms of traditional (syntactical) musical analysis, most rock music is simple and repetitive and predictable. ${ }^{51}$

Instead, he contends, rock music has come to place primary emphasis on timbre or tone color:

Rock is a music of very specific sound qualities and their textural combination. Specific sounds are as central to the music as are specific colors in painting. . . Employing recording as their primary medium, rock musicians have become painterly. But not neo-classical painters like Jean Ingres and Jacques-Louis David, who insisted that color is

${ }^{51}$ Theodore Gracyk, Rhythm and Noise 57 (1996). The reuse of basic chord changes has inspired at least one wickedly funny sketch, in which the Australian group Axis of Awesome performs excerpts of 36 popular songs using the same four chords. See Axis of Awesome, "Four Chord Song," http://www.youtube.com/watch?v=5pidokakU4I . 
subordinate to line and drawing. They are painters in the tradition of Eugène Delacroix, for whom color is the essence of the art. ${ }^{52}$

Consider, for example, the Beatles' recording of "A Hard Day's Night." Analyses by John Stevens ${ }^{53}$ and Alan W. Pollack ${ }^{54}$ show that the song has some melodic and harmonic originality; they also show that the song has a traditional 12-bar blues, AABA structure, and that it has nowhere near the theme-and-variations complexity that would be found in a piece by Bach or Mozart. But what may set the recording apart, more than any other feature, is the opening chord, a stunning sonic experience. ${ }^{55}$ Musicians have debated for decades how to best analyze that chord, and officially published transcriptions have fallen woefully short of enabling performers to duplicate it. In 2004, Jason Brown, a mathematician at Dalhousie University, did an analysis of the sound recording using a mathematical operation called a Fourier Transform. It revealed that the chord was composed of 48 frequencies that exceeded a certain amplitude threshold. Brown then speculated about how each frequency was generated, and concluded that in addition to the two guitars, bass and drum played by the members of the Beatles, some of the frequencies were likely generated by George Martin playing piano. ${ }^{56}$ A video more recently posted on YouTube adds that the sustain pedal of the piano was likely pressed, allowing the unplayed strings of the piano to vibrate sympathetically with the pitches generated by the other instruments, and that the frequencies below 100 Hertz were filtered out to prevent "muddiness" in

${ }^{52}$ Id. at 61, 66. For other similar observations, see, e.g., David Brackett, "Music," in B.Horner \& T. Swiss, Key Terms in Popular Music and Culture 126 (1999) ("most recent popular music...generates its musical interest through subtle inflections of rhythm, pitch, and tone colour within a repetitive formal frame work"); Lionel Bently, Authorship of popular music in UK copyright law, 12 Information, Communication \& Society 179 (2009); Aaron Keyt, An Improved Framework for Music Plagiarism Litigation, supra note 41, at 432 ("Since the 1950s, popular songs have moved beyond an exclusive focus on melody, chords, and lyrics, to a more imaginative use of rhythm, phrasing, bass lines, instrumentation and new technological effects, all of which can play an important role in a song's originality."); Daniel J. Levitin, This is Your Brain on Music 52 (2006) (describing the revelation that " $[t]$ imbre was what defined rock").

53 See John Stevens, Hard Day's Night - The Beatles - Musical Analysis, http://www.berkleeshares.com/songwriting_arranging/hard_days_night_beatles_mus ic analysis.

${ }^{54}$ See Alan W. Pollack, Notes on "A Hard Day's Night," http://www.icce.rug.nl/-soundscapes/DATABASES/AWP/ahdn.shtml

${ }^{55}$ To see a video that presents the chord and an analysis that is consistent with Jason Brown's as described below, see http://www.youtube.com/watch?v=2wbNaEXmyrw.

${ }^{56}$ See Jason I. Brown, Mathematics, Physics, and A Hard Day's Night, Canadian Mathematical Society Notes 36 (2004), 4-8, available at http://www.mscs.dal.ca/-brown/n-oct04-harddayjib.pdf. 
the sound. ${ }^{57}$ The result is a complex sound that is instantly recognizable by many people as the sound of the Beatles.

Tone color and complex harmonies are not the only details brought into the aesthetic foreground by recording; so are notes outside of the traditional 12-note Western scale, as two quite different examples show. First, as Michael Chanan recounts, Bela Bartok's experience with quarter-tone inflections in eastern European and Mediterranean music "became a major influence on his own style of composition. On Bartok's own admission, recording played a seminal role in reawakening his hearing to the presence and significance of these various subtle powers of expression." ${ }^{\text {t }}$ Second, as Olufunmilayo Arewa has written, ${ }^{59}$ recordings of blues musicians have raised aesthetic awareness of the use of microtones within that tradition. Joseph L. Monzo has undertaken a careful analysis of Robert Johnson's vocals on his recording of "Drunken Hearted Man," ${ }^{60}$ and through the use of expanded staff notation and two other types of charts, he visually represents how Johnson departs from equal-tempered pitches in his vocals. ${ }^{61}$ Of course, microtonal blues singing also was and is passed down between musicians through live performance and training. However, the repeated listening enabled by recording does allow for a kind of appreciation and analysis that is impossible when listening to fleeting live vocals a single time. ${ }^{62}$ And, of course, recordings do enable people widely separated in space and time - such as Eric Clapton and Keith Richards, who learned of Johnson's work on the other side of the Atlantic Ocean long after Johnson had died - to learn of and imitate unnotated elements.

${ }^{57}$ See supra note 48.

${ }^{58}$ Michael Chanan, Repeated Takes: A Short History of Recording and Its Effects on Music 11 (1997).

59 See Olufunmilayo B. Arewa, Blues Lives: Promise and Perils of Musical Copyright, 27 Cardozo Arts \& Ent. L.J. 573 (2010).

${ }^{60}$ See http://www.youtube.com/watch?v=hbwLznhwIQ8

${ }^{61}$ See Joseph L. Monzo, Uses of Microtones in the Vocals of Robert Johnson, http://sonic-arts.org/monzo/rjohnson/drunken.htm.

${ }^{62}$ See, e.g., Theodore Gracyk, supra n. 42, at 55 ("Like every aspiring rock musician, \{John] Fogerty studied his favorite recordings and 'memorized every note.' In doing so, the 'edge' and 'size' of the sound were absorbed along with the notes played."); Rob Bowman, "The determining role of performance in the articulation of meaning: the case of 'Try a Little Tenderness,"' in Analyzing Popular Music 125, 129 (Allan F. Moore, ed. 2003) ("For the last one hundred years or so we have lived in a society where recordings have become the primary means both of dissemination and learning of music. This is oral culture as process where nuances such as timbral variation, rhythmic articulation, pitch gesture and arrangements are at least as, if not more, important than lyrics, chord progression and melody."). 


\section{B. From Faithful Capture of Aural Reality to Aural Fictions}

Jonathan Sterne has argued in his book The Audible Past ${ }^{63}$ that the technology of sound recording did not just neutrally spring forth, but became possible only when people started to imagine an audible past that could and should be preserved. Such an imagination was surely connected with the imagination of the visible past, and with the belief that photography, developed before phonography, enabled unmediated preservation of fleeting moments in the visible world. As William H.F. Talbot put it, writing in 1839, photography was a "process by which natural objects may be made to delineate themselves, without the aid of an artist's pencil." ${ }^{64}$ In the last decades of the nineteenth century, Thomas Edison, Alexander Graham Bell, Emile Berliner, and others all became interested in developing a means by which sound could similarly engrave itself on a durable medium, and spring forth from those engravings at a later time. Thus, they all worked on implementing principles of transduction - the conversion of acoustical energy into mechanical or electronic energy ${ }^{65}$ - to create stable physical configurations like wavy grooves that could be reconverted into acoustical energy through transduction in the opposite direction. Machines that implemented those principles became known as phonographs (Thomas Edison's term) or gramophones (Emile Berliner's term).

As phonograph records entered commerce, that is how they were sold - as mirrors of aural reality that could preserve sound from a particular place and time. Francois Barraud's painting "His Master's Voice," ${ }^{66}$ used extensively as a trademark for both the Victor Talking Machine Company in the United States and the Gramophone Company in England, pushes the sales pitch into the realm of the macabre. In that painting, a dog - an animal known to have an acute sense of hearing - is sitting entranced at the mouth of a gramophone horn. Issuing forth from the horn is the voice of his master, even though, in

${ }^{63}$ See Jonathan Sterne, The Audible Past: Cultural Origins of Sound Reproduction (2003).

${ }^{64}$ William H.F. Talbot, Some Account of the Art of Photogenic Drawing, or the Process by Which Natural Objects May Be Made to Delineate Themselves Without the Aid of an Artist's Pencil, Royal Society of London, Jan 31, 1839; see Christine Haight Farley, The Lingering Effects of Copyright's Response to the Invention of Photography, 65 U. Pa. L. Rev. 385, 395-402 (2004). For a parallel story of how western literature moved towards naturalism, see Erich Auerbach, Mimesis: The Representation of Reality in Western Literature (1953).

${ }^{65}$ On transduction and transducers, see Jay Hodgson, Understanding Records: A Field Guide to Recording Practice 2 - 3 (2010); Jonathan Sterne, The Audible Past: Cultural Origins of Sound Reproduction 22 (2003).

${ }^{66}$ See http://en.wikipedia.org/wiki/File:His_Master\%27s_Voice.jpg. 
the story that Barraud intended to portray, his master is dead. The gramophone could thus not just freeze time, but magically bridge the gulf between life and death.

If the early phonographs were hardly perfect mirrors, the imaginative hold of representing aural reality continued, and improvements in technology were typically portrayed as enabling better representation. Thus, various improvements after World War II were marketed as producing not just a wider variety of sound frequencies, but "high fidelity" - reproduction that was more faithful to aural reality. Stereophonic sound reproduction was developed and marketed, not just to provide interesting spatial effects, but as a recreation of the directionality and aural perspective of natural hearing. Mercury Records, for example, released its stereo "Perfect Presence Sound Series," RCA its "Living Stereo" recordings, Elektra its "Panoramic Stereo" LPs. ${ }^{67}$ As the narration to a 1957 advertising film by RCA put it - with a performance of Tchaikovsky's Romeo and Juliet by Charles Munch and the Boston Symphony in the background - "almost every home music lover is in search of the same thing: the truest, most lifelike reproduction of the original music possible ... or ... perfect fidelity." ${ }^{\prime 6}$

Writers have used a number of different terms to describe recordings within this model. John Andrew Fisher calls such recordings "veridic," because they try to be "true-to-performance." ${ }^{6}$ Virgil Moorefield has described such recordings as "figurative," in the sense that, like figurative art, they purport to represent something in the world, in this instance a musical performance. ${ }^{70}$ He has also said that recording's metaphor is one of "mimetic space," in which the object is to give an "illusion of reality." "11 Theodore Gracyk has used the phrase "recording realism" to name the view that "any

67 See the display of banners from stereo LP covers at http://en.wikipedia.org/wiki/File:Stereo_Stack-A_kaleidoscopic-wonderland_of_hifidelity_and_dual-dynamic_vibrancy.jpg

${ }^{68}$ See RCA Victor, "How to Listen to ... New Dimensions in Sound" (1957), http://www.youtube.com/watch?v=ziMw7uh9VNo. Some readers will recall that in the 1970s and 1980s, Memorex had a television and print advertising campaign that used the tagline "Is it live, or is it Memorex?," thus carrying on the tradition of marketing sound recording as faithful capture.

${ }^{69}$ See John Andrew Fisher, "Rock 'n' Recording: The Ontological Complexity of Rock Music," in Musical Worlds: New Directions in the Philosophy of Music 108, 115 (P. Alperson, Ed., 1998).

${ }^{70}$ See Virgil Moorefield, The Producer as Composer: Shaping the Sounds of Popular Music 29 (2005) (contending that from Revolver onwards, the Beatles "dispensed with the concept of realism or what could be called 'figurative' recording").

${ }^{71} I d$. at xiii. 
mechanical recording is essentially the documentation of some independent reality." ${ }^{72}$ William Moylan has used the metaphor of transparency, noting that in this model, "[t]he recording medium is . . . called upon to be transparent." ${ }^{73}$ The aim of recordings in this model, states Albin Zak, is to be a "transparent documentary representation." 74

The language that we have to speak of works that are to be rendered by machines as sound sequences is still heavily influenced by the imagination of a transparent window into an aural past. It is difficult, in ordinary conversation as in law, to avoid words like "recording," with its connotation of documenting aural reality. Yet from the very beginning of the "recording industry," musicians and technicians worked to create a product that was pleasing to the ear, even though the musicians had to alter their live performance style when making a recording, ${ }^{75}$ and even though the playback did not recreate the experience of being present at a live musical performance. At first, these deviations from live performance practice and result could be explained away as stemming from the imperfection of transduction technologies. The goal, one could argue, was still a perfect representation of a live performance; musicians had to change performance styles in order to simulate live sound in the face of imperfect capture and playback, and if the playback still wasn't perfect, that was just the result of technological shortcomings.

Beginning largely in the 1950s, however, most popular music has steadily and consciously moved away from the model of transparent recordings of real-time performances. The recording, or audio work, has become a focus of creative effort and unit of creative production in its own right. People who produce recordings think much less in terms of transparent presentations of musical performances, and more in terms of collections and sequences of sound that exhibit some set of desired qualities: they are consonant or dissonant, regular or jagged, soothing or grating, crooning or wailing. Correlatively, most members of the audience for popular music do not expect or desire authenticity and transparency in a sound recording; they recognize that recordings are largely opaque stews of musical sound, and are

\footnotetext{
${ }^{72}$ See Theodore Gracyk, Rhythm and Noise 39 (1996).

${ }^{73}$ See William Moylan, The Art of Recording: The Creative Resources of Music Production and Audio 81 (1992).

${ }^{74}$ See Albin J. Zak III, The Poetics of Rock: Cutting Tracks, Making Records 7 (2001).

${ }^{75}$ On such alterations, see Mark Katz, Capturing Sound: How Technology Changed Music 42-45 (2010).
} 
interested in sonic experiences in their own right. ${ }^{76}$ Third, the process by which recordings are made, although varying, has typically come to involve little or no reliance on written scores, and far more editing and manipulation of real-time human musical performances (and sometimes avoidance of realtime performances altogether).

There are many milestones in the evolution from captured performance to audio work. Theodore Gracyk contends that the best candidate for time and place of the birth of "the rock aesthetic of creativity through recording" was 1954 at Sun Studios in Memphis, when Elvis Presley, with producer Sam Phillips, guitarist Scotty Moore, and bassist Bill Black, made recordings such as "Good Rockin' Tonight," 77 "Mystery Train," "That's Alright Mama." That aesthetic had implications for both process and product. As for process, Dave Marsh has written:

Elvis, Scotty, Bill and Sam built their music in the recording studio, the first time anyone had ever created a major musical innovation except by working it out in front of a live audience or by laboriously composing it on paper first. Magnetic recording tape had only recently made it possible to do a take of a song, listen to a playback, analyze it, then try another rendition and repeat the process. ${ }^{80}$

Listening to the playback did not just mean hearing where a note was played too long or sung too sharp and should be corrected. It meant listening to the playback as sound, and concentrating on sculpting the sound of the finished product. Concentration on that sound led to experimentation both with reverberation or "reverb," and with progressively more complicated echo effects. Sam Phillips installed a specially-wired two-tape-recorder setup that created an echo or "slap-back" 81 by mixing the initial recording with the

\footnotetext{
${ }^{76}$ To be sure, authenticity has been a major theme in twentieth-century popular music as well, and it has sometimes surfaced in the form of a desire for recordings that are veridic representations of "authentic" live performances. However, authenticity is a much more complex and variable concept, which includes authenticity as emotional autobiography and authenticity as un-self-aware cultural (and racial) purity. For a critical review of the uses of authenticity in popular music, see Hugh Barker and Yuval Taylor, Faking It: The Quest for Authenticity in Popular Music (2007).

${ }^{77} \mathrm{http}: / /$ www.youtube.com/watch? $\mathrm{v}=\mathrm{rO}$ _rldrXnOI

${ }^{78} \mathrm{http}: / /$ www.youtube.com/watch? $\mathrm{v}=\mathrm{Q}$ eEONPArEY

${ }^{79} \mathrm{http}: / /$ www.youtube.com/watch?v=hIWlWAlYTBw

${ }^{80}$ Dave Marsh, Elvis 28 (1982), quoted in Theodore Gracyk, Rhythm and Noise: An Aesthetics of Rock 14

${ }^{81}$ While "echo" may and typically does have several progressively smaller delayed peaks or regenerations, "slap-back" or "slap echo" consists of a single repetition. See
} 
playback of that recording a fraction of a second later as the tape passed a second head. ${ }^{82}$ That setup applied uniform echo to the whole recording. Jack Clement, an engineer who started working at Sun Studios in 1956, further refined the technique, by incorporating a sub-mixer that allowed him to apply slap-back selectively, causing some instruments and voices to echo more than others, and thus creating different senses of space on a single recording. ${ }^{83}$

As Greg Milner has noted, "[s]lap-back was the very antithesis of high fidelity - not just because it distorted the signal, but also because it had nothing to do with capturing a performance." 84 Those involved with creating the recording were now focusing on the sound experience of the recording as the product, independent of anything that could be heard live in the recording studio. Jack Clement put it succinctly: "I wasn't trying to deal with reality. I was trying to improve on it." 85

The overall result, argues Theodore Gracyk, is that the recording erases "any distinction between the performance and the musical work":

This music unifies an interpretation with a specific sound medium as inseparable parts of a single work; each listener who learns these songs

Wikipedia, Delay, http://en.wikipedia.org/wiki/Delay . The rarity of a single perfectly-defined repetition in nature may make slap-back feel artificial, otherworldly, and novel.

${ }^{82}$ For some details on the tape recorder setup at Sun Studios, see the footnote on "Sun Tape Echo" towards the bottom of the page entitled "Elvis at Sun: An Overview of the Audio Restoration," http://www.elvisrecordings.com/r_elvisatsun.htm. At Chess Records in Chicago, Leonard Chess engaged in similar experimentation through acoustic means, "placing open microphones in toilets and sections of sewer pipe suspended from the ceiling," and eventually building a separate echo chamber in the basement of the studio. D. Thomas Moon, "Strange Voodoo: Inside the Vaults of Chess Studios," Blues Access No. 36 (Winter 1999), http://www.bluesaccess.com/No_36/chess.html

${ }^{83}$ Greg Milner, Perfecting Sound Forever: An Aural History of Recorded Music 152 (2009). Guitarist Scotty Moore also began to use a guitar amplifier that had its own built-in tape delay, allowing the guitar to echo differently than everything else. See Peter Doyle, Echo and Reverb: Fabricating Space in Popular Music, 1900-1960 188 (2005).

${ }^{84}$ Greg Milner, Perfecting Sound Forever 151.

${ }^{85} \mathrm{Id}$. at 152 . Les Paul was another great innovator, who did important work before the Presley Sun Studios sessions. He was one of the pioneers of multitrack recording, of intentionally varying recorded speed, and of using echo and reverb. His 1951 hit recording of "How High the Moon" with his wife Mary Ford, which was created by overdubbing both his guitar and Mary's voice 12 times, must be considered another milestone in the transformation from captured performance to audio work. See http://www.youtube.com/watch?v=Ng8a5Df2V50. 
through these recordings grasps every aspect as properties of a total musical work. The timbre of Presley's voice, the phrasing, even the sound of his voice on that particular day, is as much a part of the musical work as the melody or the syncopation. ${ }^{86}$

Of course, it is worth recalling that the Presley Sun Studio recordings represent an incremental step. Presley was working with songs that others had written, ${ }^{87}$ and each recording was generated without overdubbing or splicing, from one continuous real-time performance, even if Presley had recorded many other performances and listened to those recordings before creating the recording that was publicly released.

The story of the next several decades of the sound recording in popular music can be told in several ways. One could describe all of the new technologies that have been introduced since the 1950s. These include multitrack recording, various kinds of sound processing, synthesizers and electronic sound synthesis, and sequencers. ${ }^{88}$ Beginning in the 1980s, the introduction of computers led to the recreation of all of these tools in digital form, and the addition of new digitally implemented techniques, such as realtime pitch alteration of singing, popularized under the brand name AutoTune, ${ }^{89}$ and digital sampling. ${ }^{90}$

One could also describe some of the most famous ways those technologies were used to create distinct sound styles, from the use of echo chambers to create Phil Spector's "Wall of Sound,"" to the use of compressors

${ }^{86}$ Theodore Gracyk, Rhythm and Noise: An Aesthetics of Rock 14 (1996) (emphasis in original).

${ }^{87}$ It is worth noting that many songs recorded by Elvis Presley were written and previously recorded by African-Americans who due to racism could not enter the White popular music market, and who often had signed contracts that gave them little or no royalties, or were otherwise cheated out of royalties. For the story of Arthur Crudup, composer of "That's Alright Mama," and the fight to obtain royalties that succeeded only after his death, see Dick Waterman, Between Midnight and Day: The Last Unpublished Blues Archive (2003).

${ }^{88}$ For a recent systematic review of all of these technologies, see Jay Hodgson, Understanding Records: A Field Guide to Recording Practice (2010).

${ }^{89}$ See http://en.wikipedia.org/wiki/Auto-Tune.

${ }^{90}$ For a history and prehistory of digital sampling, see Kembrew McLeod and Peter DiCola, Creative License: The Law and Culture of Digital Sampling 19-74 (2011).

${ }^{91}$ The "Wall of Sound" style used large ensembles and overdubbing, combined with an echo chamber, to produce a rich, blended sound that was successful in part because it sounded good on transistor radios, which were becoming popular at the time. See Wikipedia, "Wall of Sound," http://en.wikipedia.org/wiki/Wall_of_Sound. Classic Wall of Sound recordings include The Ronettes, "Be My Baby," 
and noise gates to create the 1980s gated drum sound, ${ }^{92}$ and the use of AutoTune by artists like Cher ${ }^{93}$ and T-Pain, ${ }^{94}$ not to mask off-key singing, but to create a distinctive synthesized vocal style.

The point here, however, is that these all reveal that the typical product for sale as popular music is not a transparent, veridic "recording" of any performance, but a carefully constructed audio fiction, that like all fiction takes its place in what has by now become a rich literature.

\section{The Move Away from Musical Notation}

Although there is plenty of anecdotal evidence that musical notation has become less important to the creation of musical works, that shift is demonstrated more systematically by an analysis of more than 4.5 million musical-work copyright registrations at the United States Copyright Office from 1978 through 2012. When an author applies to register a claim of copyright in a work, he or she must deposit copies of that work. Information about the type of deposit made - in the case of musical work registrations, principally either musical notation or a sound recording (technically, a phonorecord) - is preserved in the registration record. Figure 1 summarizes the results of a study of the types of deposits submitted with over 4.5 million musical work registration applications from 1978 through 2012.

The bar chart presents an estimate of the percentages of musical work registrations made each year on the basis of, respectively, notation deposits and phonorecord deposits. In 1978, 86\% of musical works registered were accompanied by deposits of notation, and only $14 \%$ by phonorecord deposits. By 2012,77\% of musical work registrations were accompanied by phonorecord deposits, and only $17 \%$ by deposits of musical notation (6\% were accompanied only by deposits of text - lyrics - and hence technically did not qualify as musical works).

http://www.youtube.com/watch?v=QzhbGaCwBzs and Ike and Tina Turner, "River Deep Mountain High," http://www.youtube.com/watch?v=tipw66XjXn4.

92 See Greg Milner, Perfecting Sound Forever 152 (2009). A classic gated drum recording is Phil Collins, "In the Air Tonight" (1981), see Wikipedia, "In the Air Tonight", $\quad$ http://en.wikipedia.org/wiki/In_the_Air_Tonight; http://www.youtube.com/watch?v=YkADj0TPrJA.

${ }^{93}$ See Cher, "Believe" (1998), http://www.youtube.com/watch?v=LbXiECmCZ94.

94 See, e.g., T-Pain, "Can't Believe It" (featuring Lil Wayne) (2008), http://www.youtube.com/watch?v=kWBE0sQC5L8; Plies, "Shawty" (featuring TPain) (2007), http://www.youtube.com/watch?v=vJ7k0XZqdaU. 


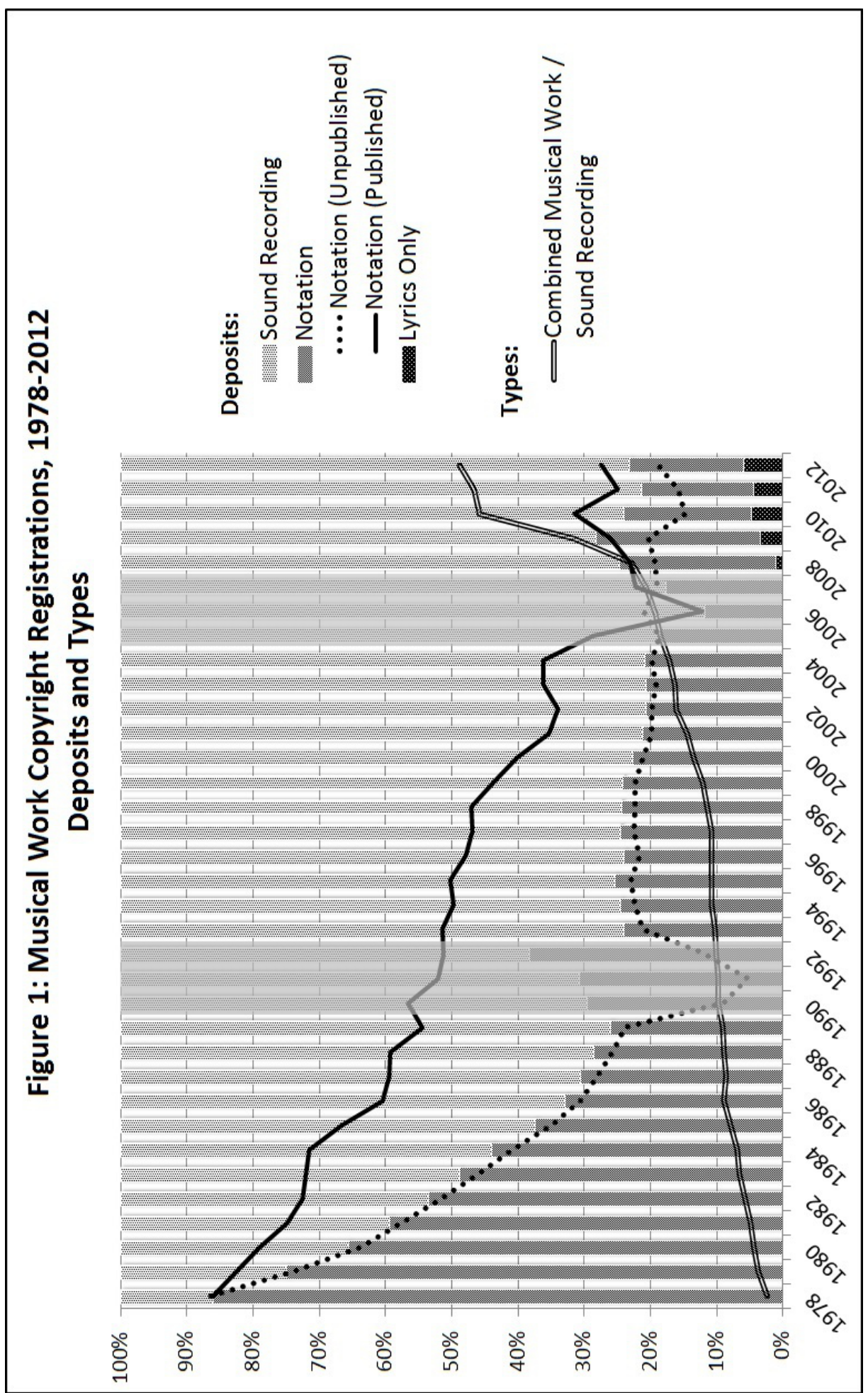

The solid line in the chart shows the percentage of published musical 
work registrations accompanied by deposits of musical notation. Throughout the 1980s and 1990s, that percentage remains substantially higher than the percentage of all musical work registrations accompanied by notation deposits. To the extent that the distinction between published and unpublished musical works serves as a rough proxy for professional and amateur authors, it appears that professional composers and publishers stuck with notation longer. By 2012, however, only about $27 \%$ of published musical work registrations are accompanied by notation; nearly three-quarters are accompanied only by sound recordings.

The dotted line shows the percentage of unpublished musical work registrations accompanied by notation deposits. For the most part, it more closely follows the percentage for all musical work registrations shown in the bar chart, for the simple reason that there are many more unpublished than published musical works registered, and hence that unpublished registrations more heavily influence the overall numbers. Two periods - the three-year period of 1990-1992, and the three-year period of 2005-2006 - are shaded. For most years, a large percentage of musical work registrations contain information about accompanying deposits - on average, excluding those six years, about $90 \%$. During those six years, however, far fewer musical work registrations contain deposit information - on average, fewer than 30\% - and for unknown reasons those that do may not be representative, leading to some likely anomalies in the figures presented.

Lastly, the double line reveals something interesting, not about the types of deposits made, but about the types of registration applications filed. Since 1978, claimants can choose to file either an application to register a musical work by itself, or a combined application to register both a musical work and a sound recording. The latter requires the applicant to submit a single phonorecord deposit for both claimed works. The double line shows the percentage of all musical work registrations that were filed each year as combined musical work / sound recording applications. In 1978, only two percent of musical work registrations were filed as combined musical work / sound recording applications; 98\% were filed for musical works alone. In the 30 years from 1978 to 2008, the percentage of combined applications slowly but steadily increases, from 2\% to 23\%. Then, from 2008 through 2012, the percentage increases more sharply. By 2012, 49\% of all registrations of musical works are being filed as combined registrations of musical works and sound recordings, with a single phonorecord deposit. One interpretation, at least, is that the more and more claimants are simply trying to register 
whatever is copyrightable in the phonorecords that they deposit, and are not focused on the distinction between musical work and sound recording. ${ }^{95}$

\section{THE DiFFICULTY OF SPLITTING COMPOSITION FROM PERFORMANCE UNDER A CONSERVATIVE INTERPRETATION OF THE 1976 ACT}

Recall that the Copyright Act of 1976 worked a potentially enormous change in music copyright law when it recognized protection for phonorecord-embodied musical works, rejecting the view, which had been in place for the entire history of U.S. copyright law, that musical works were works fixed in written notation. Moreover, Congress apparently meant to have this change in perspective apply retroactively. ${ }^{96}$

The removal of the written notation requirement could be read as recognizing that there are phonorecord-embedded musical works that are works of authorship of a different kind than notated musical works, and that such works deserve to be treated on their own terms, as extending to all of the repeatable musical experience fixed in the phonorecord, just as a notated musical work includes every element of notation. However, the 1976 Act also

\footnotetext{
${ }^{95}$ For a more detailed explanation of this copyright registration study, and of the methodology underlying it, see the online note at http://docs.law.gwu.edu/facweb/rbrauneis/musicalworkcopyright/musicalworkregist rations.htm.

${ }^{96}$ I come to this last conclusion primarily from a reading of the Ninth Circuit's decision in ABKCO Music, Inc. v. LaVere, 217 F.3d $684\left(9^{\text {th }}\right.$ Cir. 2000), as well as from the Copyright Office's statement in its Compendium II of Copyright Office Practices. .ABKCO Music involved two of the songs that Robert Johnson had recorded back in 1936 - "Love in Vain" and "Stop Breakin' Down." Before 1978, they had never been registered, and it seems pretty clear that they had never been fixed in notated form by Johnson or by anyone authorized by him or his successors. In 1974, Stephen LaVere located Carrie Thompson, Johnson's sister, who was thought to be Johnson's only living heir, and entered into an agreement with her to try to generate income from Johnson's compositions in return for a 50\% share of royalties generated. ${ }^{96}$ In 1991, LaVere registered the two Johnson compositions at issue, along with 22 others. See, e.g., "Love in Vain," U.S. Copyright Registration No. PA0000546956 (April 9, 1991). As a deposit, he submitted, not scores for any of the compositions, but a phonorecord - a 1990 Columbia rerelease of the Robert Johnson recordings on two CDs. While the Ninth Circuit's direct holding is that the 1936 and 1937 recordings did not publish the songs, the ABKCO Music litigation seems to assume that those recordings did fix those songs, and that the 1976 Act's rule that fixation of musical works in phonorecords is sufficient to obtain federal copyright protection is retroactive, encompassing all musical works that were fixed only in phonorecords before 1978. Section 405.03 of the Compendium of Copyright Office Practices (Compendium II), published in 1984, states simply: "music embodied only in phonorecords before 1978 is now acceptable for registration in that form."
} 
preserves two limitations on copyright in sound recordings that were introduced in the Sound Recording Act of 1971. Under $\$$ 114(b), the reproduction and derivative work rights in sound recordings are limited to copying by electronic or mechanical processes, ${ }^{97} \$ 106(4)$ excludes sound recordings from the general right of public performance ${ }^{98}$ and $\$ \mathbb{S} 106(6)$ and 114(d) through $114(\mathrm{~h})$ grant them only a limited digital audio transmission right. ${ }^{99}$ One possible interpretation of these limitations, read together with the grant of copyright protection to phonorecord-embodied musical works, is that the musical works embodied in phonorecords are not co-extensive with the sound recordings embodied in those same phonorecords, but rather consist only of some features of that sound. Those features, as we will see, are typically identified as compositional features, whereas the other features, which form part of the sound recording but not the musical work, are identified as performance features. I will dub this interpretation of the 1976 Act the "conservative" interpretation because under it, the 1976 Act preserves much of the approach to musical works and sound recordings established in the Sound Recording Act of 1971: the composition/performance distinction stands, and performances are granted less protection than compositions.

If there were one clear way of isolating a subset of features within a musical sound recording that constituted the musical composition, and separating them from performance features, then it might be tempting to adopt the conservative interpretation of the 1976 Act as best fitting the language of the Act's provisions, whether or not it expresses the best policy approach. However, this Part will argue that, in trying to isolate musical works within sound recordings, courts and commentators have adopted, not one approach, but a varying and unstable combination of four approaches, and that all of these approaches are difficult to apply to sound recordings. The failure to articulate a workable approach for isolating musical work from sound recording raises an administrability problem that stands in the way of adopting a conservative interpretation, and requires another look at a more radical interpretation, which will be the subject of Part IV.

A. Support for Preservation of a Composition/Performance Distinction in Legislative History, Judicial Decisions, and Commentary

The preservation of a composition/performance distinction to isolate musical works within sound recordings finds some support, not only in the

\footnotetext{
${ }^{97}$ See 17 U.S.C. $\$ 114(b)$.

${ }^{98}$ See 17 U.S.C. $\$ 106(4)$.

${ }^{99}$ See 17 U.S.C. \$106(6); 17 U.S.C. $\$ \$ 114(d)-114(h) ;$
} 
language of $₫ 114(\mathrm{~b})$, but also in legislative history, in judicial decisions, and among commentators. Thus, for example, the House Report to the 1976 Act states that " $[\mathrm{m}]$ ere imitation of a recorded performance would not constitute a copyright infringement even where one performer deliberately sets out to simulate another's performance as exactly as possible." ${ }^{100}$ Although this statement does not explicitly refer to musical performances, there is other legislative history suggesting that musical performances are exactly what some participants in the legislative process had in mind. ${ }^{101}$ Thus, the idea vague though it might be, and conceived of at a time when notated musical works, as the only protected musical works, could serve as an anchor for defining the musical work generally - is that within every musical sound recording, there will be some aspects of sound that will be merely products of "performance," and that will therefore be protected only against mechanical or electronic copying and not against independently fixed imitation, whereas other aspects of sound will form the "musical composition" or "musical work," which will be fully protected against imitation.

In the face of this complicated scheme and history, most courts appear to have adopted some variation of a conservative interpretation, under which musical works consist of the compositional elements within a sound recording that contains both compositional and performance elements. Thus, for example, in Swirsky v. Carey, ${ }^{102}$ the Ninth Circuit approved of the plaintiff's expert's omission of some notes a vocalist sung and other notes a bass player played in comparing plaintiff's and defendant's recordings, because those were characterized as "performance-related" and "ornamental" rather than "compositional elements" and "structural." ${ }^{103}$ In Newton v. Diamond, ${ }^{104}$ the

${ }^{100}$ Copyright Law Revision, H. Rep. No. 94-1476, at 106; see id. ("statutory protection for sound recordings extends only to the particular sounds of which the recording consists, and would not prevent a separate recording of another performance in which those sounds are imitated").

${ }^{101}$ See Copyright Law Revision Part 3, Preliminary Draft for Revised U.S. Copyright Law and Discussions and Comments on the Draft, p. 196 (comments of Sydney A. Diamond, London Records) (meeting of April 11, 1963) (referring to a case involving a musical sound recording and then stating "If somebody goes into a studio and fixes an independent performance, that cannot possibly constitute an infringement in an existing sound recording"); see also id. at 352, 356 (letter of Sydney A. Diamond, February 11, 1963) (suggesting that sound recordings would only be protected against "dubbing")..

102376 F.3d 841 ( $9^{\text {th }}$ Cir. 2004).

${ }^{103}$ Id. at 847 . At the same time, Swirsky contemplates that not only melody, harmony, and rhythm, but also tempo, phrasing, key, genre, lyrics, and structure should be taken in to account in determining substantial similarity of musical works, which represents a comparatively broad view of such works. See id. at 848-849. 
Ninth Circuit held that the complex, shifting timbre of a note sequence in a piece of recorded music entitled "Choir" was not part of the musical work presented in that recording, because although James Newton both composed and recorded the music, only the note sequence counted as composition, while the timbre was attributable to performance technique. Similarly, in Poindexter v. EMI Record Group, ${ }^{105}$ the Southern District of New York concluded that the musical work in a recording of a piano was confined to the note played on the piano - an F sharp, as it turns out - and did not include the tone quality of the piano as it varied over time. Only the Sixth Circuit, in Bridgeport Music, Inc. v. UMG Recordings, Inc., ${ }^{106}$ has used language that is conceivably compatible with the view that sound recording and musical work can be coextensive. In that case, involving the George Clinton song "Atomic Dog," it rejected objections to the District Court's decision to allow the jury to consider several elements that featured in both plaintiff's and defendant's independently fixed sound recordings, including "repetition of the word 'dog' in a low tone of voice at regular intervals" and "the sound of rhythmic panting." Because "Atomic Dog" was created in a recording studio without a written score, the court stated, "the composition of "Atomic Dog" is embedded in the sound recording." 107

Some commentators have also advocated a conservative interpretation. David Nimmer, criticizing the Bridgeport Music case, opines that some elements of a sound recording would fall outside of the musical work embodied in that recording: "If George Clinton's distinctive voice or the timbre of guitars and drums were copied by defendant, any redress would lie solely for the sound recording copyright, not for that of the musical composition."108 He therefore argues that the Sixth Circuit was wrong in allowing the jury to consider the two elements above. Professor Jamie Lund has conducted an important set of experiments which demonstrated that listeners are often influenced in their perceptions of similarity between two musical sound recordings by such matters as tempo, key signature,

\footnotetext{
${ }^{104} 349$ F.3d 591 ( $9^{\text {th }}$ Cir. 2003).

1052012 WL 1027639 (S.D.N.Y.).

106585 F.3d 267 (6 $6^{\text {th }}$ Cir. 2009).

${ }^{107} \mathrm{Id}$. at 272. It might be reading too much into the court's statement to conclude that "embedded" means "possibly coextensive," for in a footnote appended to that statement, the court quotes the standard definition of a musical work as consisting of rhythm, harmony, and melody. Nonetheless, the court's willingness to include "the repetition of the word 'dog' in a low tone of voice at regular intervals" and "the sound of rhythmic panting" suggests a broad view of what sounds count as part of the musical work.

${ }^{108}$ Melville B. Nimmer \& David Nimmer, Nimmer on Copyright $\$ 2.05$ [A].
} 
orchestration, and style. ${ }^{109}$ Her normative conclusion, however, is that courts should be wary of playing sound recordings to juries, because those aspects of music lie outside of the "dominant" musical work definition limited to "rhythm, harmony and melody." 110 Since sound recordings contain both "performance" elements and "composition" elements, they could lead juries to find musical works to be more or less similar than they actually are.

B. Separating Composition from Performance within Sound Recordings: Not

One Approach but Four, Applied Inconsistently and with Difficulty

It cannot be my aim here to conclusively demonstrate that isolation of musical works within sound recordings along any composition/performance lines is infeasible and suboptimal. I do, however, want to convey some strong doubts. I will argue that there is not one single approach to or test for separating composition from performance implicit in the analyses of courts, advocates, and commentators, but four such approaches. Even in pre-soundrecording days, those approaches often diverged from one another, and they certainly diverge when applied to sound recordings. I will also argue that the tests used to separate composition from performance are very difficult to apply to sound recordings in any way that would reflect some different cost structure with regard to creation or enforcement, and hence that would therefore provide some reason to distinguish them from the point of view of copyright policy.

I will call the four approaches the notation approach; the etiology approach; the macro/micro approach; and the musical analysis approach. The notation approach asks: did that feature of musical sound stem from musical notation, or can it be represented in notation? The etiology approach asks: was that feature created through a deliberative, non-real-time process, or a spontaneous, real-time one? The macro/micro approach asks: does that feature appear only on a scale of more than one note or chord, or does it appear within a single note or chord? The musical analysis approach asks: is that feature a basic part of the harmonic, melodic, or rhythmic structure of the piece, or is it incidental thereto?

Consider, first, a hypothetical situation in which all four approaches might line up with each other to create the sense that composition and performance are really two separate activities that result in two separate products. Suppose that one person created a notated composition with lyrics,

${ }^{109}$ See Jamie Lund, An Empirical Examination of the Lay Listener Test in Music Composition Copyright Infringement, 11 Va. Sports \& Ent. L. J. 117 (2011).

${ }^{110}$ See id. at 146-147 (2011). 
a song in the old-fashioned sheet music sense of the word, entitled "Someone Like You." That song contained the line "Never mind, I'll find someone like you," and a notated melody to which the line was supposed to be sung. The notated melody for the word "you" consisted of a single note. Along comes a singer. The very first time she sings the song, she adds an appoggiatura in the middle of singing the word "you." That is to say, her voice very briefly moves down a half step, and then moves back up again to conclude the word on the written note.

Adele Laurie Blue Adkins, known professionally as Adele, does in fact perform such an appoggiatura in the sound recording of "Someone Like You" that won her a 2012 Grammy Award for Best Pop Solo Performance. ${ }^{\text {Ill }}$ One scientist has claimed that that appoggiatura plays a large role in the emotional appeal of that performance. ${ }^{112}$ Some of the other facts in the paragraph above, however, have come from my imagination. Applying the four tests or approaches, we would say that (1) the appoggiatura was not part of the notated work; (2) Adele came up with it spontaneously; (3) it was a microlevel feature, within a single sung syllable, lasting for a fraction of a second; and (4) it was not marking a shift towards a basic harmonic tension or resolution in the piece. Maybe, we would say, features like that one deserve less protection than features for which all four tests came out the other way. Of course, any single feature in isolation does not deserve copyright protection (a topic that will receive further attention below), but right now we're just engaged in a filtering process, removing certain elements before conducting a substantial similarity analysis that would take a group of remaining elements into account as a whole.

\section{The Notation Approach.}

Now let us consider each approach separately, and examine how each might apply to a sound recording, and might or might not line up with the others. The notation approach obviously has strong ties to the traditional, pre-1976 Act view that copyright-protected musical works are works of notation. Results of an approach that examined actual notation would likely have some correlation to results of an etiology approach, at least in the era before computer-generated notation, since manually-generated notation likely

111 See Wikipedia, Grammy award for Best Solo Pop Performance, http://en.wikipedia.org/wiki/Grammy_Award_for_Best_Pop_Solo_Performance.

${ }^{112}$ Michaeleen Doucleff, "Anatomy of a Tear-Jerker: Why does Adele's 'Someone Like You' make everyone cry? Science has found the formula," The Wall Street Journal, February 11, 2012, http:/online.wsj.com/article/SB10001424052970203646004577213010291701378.html 
involves deliberation. Consider Newton v. Diamond, ${ }^{113}$ which touches on the issue of whether the timbre of a recorded James Newton flute performance is part of the musical work fixed in that recording. In that case, Newton had notated the work, ${ }^{114}$ and both the majority and the dissent claim to be taking the notation into account. The dissent, however, gives more weight to the fact that the notation contains a written instruction that the "piece requires singing into the flute and fingering simultaneously," and indicates the different notes to be sung and fingered, and also contains notations that the piece should be played "largo" and "senza misura."115 The majority places little emphasis on those parts of the notation, and indicates agreement with expert testimony presented by the defendants that the musical work is "merely a common, trite, and generic three-note sequence." "116 Thus, the dissent may be more purely following the notation approach, acknowledging that written notation often includes special directions that shape timbre, and not just pitches and duration. ${ }^{117}$ The majority, on the other hand, is actually headed in

113349 F.3d 591 ( $9^{\text {th }}$ Cir. 2003). For a critique of the Newton decision written by Newton's attorney, see Alan Korn, Issues Facing Legal Practitioners in Measuring Substantiality of Contemporary Musical Expression, $6 \mathrm{~J}$. Marshall Rev. Intell. Prop. L. 489 (2007).

${ }^{114}$ There are two registration records for "Axum," the collection of James Newton music that includes "Choir," the piece at issue in Newton v. Diamond. One is clearly for the sound recording as released by ECM Records. It bears the registration number SR0000034394; lists the copyright claimant as ECM; and lists the type of work as "Sound Recording." The other one bears the registration number of SRu000034748; lists the copyright claimant as James Newton; lists the type of work as "Music"; and describes the deposit as "l sound cassette." Although the "SR" registration number suggests that Newton applied to register his claim on the form appropriate for a sound recording, it turns out that a lot of claimants in musical works do that, and in those cases the Copyright Office simply issues a musical work registration under the "SR" number. A database of copyright registrations constructed by the author of this article reveals that there are over 300,000 registrations for musical works bearing "SR" numbers. James Newton may well have mistakenly used the SR form because he was depositing a phonorecord, rather than a score, in connection with his registration, as is perfectly allowable for a musical work registration after 1977. The phonorecord deposit, however, raises the issue of why the score that figures in the Newton v. Diamond litigation has any relevance at all. By using a phonorecord as a deposit, Newton was registering the musical work as it was fixed in that phonorecord, not as fixed in a score that he prepared at some time before or after he created the phonorecord, and the notated work need not be the same as the musical work fixed in the phonorecord.

${ }^{115}$ See id. at 598-600 (Graber, J., dissenting).

${ }^{116}$ Id. at 597 (majority opinion) (quoting testimony of Dr. Lawrence Ferrara).

${ }^{117}$ For further details on aspects of musical notation that concern timbre, see the online note

at http://docs.law.gwu.edu/facweb/rbrauneis/musicalworkcopyright/notationandtimbre .htm. 
the direction of the macro/micro approach, taking the position that timbre is "performance" and only larger melodic and harmonic structures are "composition."

When musical works fixed in phonorecords are at issue, the notation approach must be applied in a dramatically altered form. One has to ask what could be notated from the recording in an after-the-fact transcription, rather than what (if anything) actually was notated before, or after, the recording. If a score were fixed before a related phonorecord, the musical work fixed in the phonorecord could arguably be a more developed or altered derivative of the work fixed in the score. If the score were fixed afterwards, it is only one transcriber's interpretation of what she heard, and in many instances could itself be a derivative work intentionally altered to serve the particular demands of anticipated purchasers of sheet music. ${ }^{119}$

In the typical case, an after-the-fact transcription would result in a much thicker "musical work" than is typically represented in sheet music, let alone lead sheets. Such a transcription would capture the "arrangement" for all of the instruments and voices that were represented in the recording, and matters such as tempo, dynamics, and special performance techniques. It would also include features such as vocal melismas, ${ }^{120}$ solos, drum accents, guitar fillers, and so on, that might have been improvised on the spot or even added by mistake, thus sending the notation approach off in a different direction than the etiology approach.

Thus, for example, in Straughter v. Raymond, ${ }^{121}$ which involves plaintiff Straughter's claim that defendant Usher Raymond's song "Burn" infringed his song "The Reasons Why," the court assumes that plaintiff's expert has correctly included melismas sung in both songs in his after-the-fact

\footnotetext{
${ }^{118}$ The lower court follows a notation approach, but finds that the timbre in the recording is influenced too much by unnotated performance techniques, including overblowing of the flute. See Newton v. Diamond, 204 F.Supp. 1244, 1251-1252 (C.D. Cal. 2002).

119 Sean O'Connor recounts his own discovery that sheet music versions were intentionally modified - "simplified" - by publishing company transcribers, and flags the issue of what version counts as the copyrighted work, in Sean O'Connor, What Composers and Copyright Lawyers Can Teach Each Other Part II, at 15:40 - 16:45, http://vimeo.com/31586134.

120 "Melisma, in music, is the singing of a single syllable of text while moving between several different notes in succession." Wikipedia, "Melisma," http://en.wikipedia.org/wiki/Melisma

${ }^{121} 2011$ WL 3651350 (C.D. Cal.)
} 
transcriptions. ${ }^{122}$ There is no indication of what criterion of inclusion the expert was using (other than whatever might be beneficial to his client), but inclusion was certainly consistent with an after-the-fact transcription approach, as they are just other notes sung by the singer. By contrast, in Swirsky v. Carey, ${ }^{123}$ the court holds that the plaintiff's expert did not err in omitting sung melismas and appoggiaturas from the transcription he used to analyze substantial similarity. That is inconsistent with a notation approach, and while appoggiaturas are arguably "micro-level," melismas could be seen as more "macro-level" - they can run on for several measures, as some performances by Mariah Carey, the defendant in Swirsky v. Carey, will demonstrate. ${ }^{124}$ In Swirsky, however, Swirsky's expert justifies the omission on a combination of the etiology approach and the musical analysis approach. He seems to assume that the melismas and appoggiaturas were added spontaneously, which might or might not have been true, and he also suggests that they weren't structural - that they didn't mark harmonic changes. ${ }^{125}$ Without distinguishing between those two approaches, the court decides that the melismas and appoggiaturas were validly omitted as "performance related." 126

Is the notation approach a valid method to distinguish between composition and performance elements of sound recordings? Any use of such a method seems to fly in the face of Congress's fundamental decision in the 1976 Act to discard the notation requirement. As the Senate Report put it, the choice of broad language in $\mathbb{S} 102$ of the Act, providing that fixation in any tangible medium would be sufficient, "is intended to avoid the artificial and largely unjustifiable distinctions, derived from cases such as White-Smith

${ }^{122}$ See Straughter, 2011 WL 3651350 at *14 (“According to [plaintiff's expert,] 'Reasons' and 'Burn' share substantially similar . . . uses and placements of melisma"); id. at * 15 (Plaintiff's expert "further asserts that the stylistic use of a melisma prior to the fade out in both songs contributes to their substantial similarity"). Both "The Reasons Why" and "Burn" were created collaboratively in recording studios, and never existed in notated form. In both cases, the deposits that accompanied the musical work copyright registrations were sound recordings. See U.S. Copyright Registration PAu002313592 ("The Reasons Why"); U.S. Copyright Registration PA0001159079 ("Burn").

123376 F.3d 841 ( $9^{\text {th }}$ Cir. 2004).

${ }^{124}$ See, e.g., [HD] Mariah Carey - Best Studio Vocal Runs, Riffs \& Melismatic Phrases, http://www.youtube.com/watch?v=XlzJ8xiCFzU.

${ }^{125}$ See Swirsky, 376 F.3d at 847 (quoting Swirsky's expert as stating that he "took [melismas and appoggiaturas] to be a matter of the singer customizing the song and regarded those notes as not structural; they are ornamental").

${ }^{126}$ Id. 
Publishing Co. v. Apollo Co., 209 U.S. 1 (1908), under which statutory copyrightability in certain cases has been made to depend upon the form or medium in which the work is fixed." 127 At the very least, one would think, that approach should not be limited to notation that is intended as direction for human performance, a relic of a musical practice that is no longer exclusive or even dominant. Yet once that limitation is discarded, it is hard to know where to stop. Presumably notation for machine-synthesized and-sequenced music could be included, and such notation would be exact as to all elements of sound in a recording, including harmonics and attack-sustain-decay-release envelopes. ${ }^{128}$ Once such notation is included, there is no limit: a digital music file itself is a form of notation of the music to be rendered by an electronic device.

\section{The Etiology Approach.}

The etiology approach asks whether the feature in question resulted from the deliberate activity of composition or the spontaneous activity of performance. ${ }^{129}$ This approach may have some intuitive appeal if we value the creative labor of deliberation over spur-of-the-moment spontaneity, and if we conclude that such creative labor has more need for the incentive of copyright protection. There is some difficulty in applying this approach to any musical practice, because there seems to be a continuum of more or less deliberative acts in creating music, rather than two discontinuous categories of composition and performance. For example, many performers rehearse before performance, and a rehearsal can involve deliberation about creating music. Extensive orchestral rehearsals can involve repeated experiments, followed by choices among alternatives, and orchestra members will even frequently annotate their scores to represent the choices that that have been made, ${ }^{130}$

${ }^{127}$ Copyright Law Revision, S. Rep. No. 94-473, 94th Cong., lst Sess., at 51 (1976).

${ }^{128}$ Consider, for example, two videos which lead the viewer step-by-step through the creation of a "synth line," or synthesized music loop, of a popular electro house recording. See "How to make synth line from Bodyrox Yeah Yeah D. Ramirez Remix Sounds To Sample," http://www.youtube.com/watch?v=Kgt_trNHWJY; "Create the "Yeah Yeah" Bodyrox synth in Reason 4.0! (Tutorial)," http://www.youtube.com/watch?v=YT3u6HNWsiO. Those videos lead the viewer through adjusting a series of settings on a synthesizer, including some settings of oscillators that produce the distinctive timbres of the synth line. A listing of those settings would seem to constitute notation of every element of sound produced.

${ }^{129}$ Sean O'Connor explores this distinction in Sean O'Connor, What Composers and Copyright Lawyers Can Teach Each Other Part III, at 9:05 - 12:00, http://vimeo.com/31602019.

${ }^{130}$ For a study of 25,000 annotations made by performing musicians on scores, see Megan A. Winget, Annotations on musical scores by performing musicians: 
thus creating what might qualify as compositional elements under the notation approach. In the age of audio recording, a performer like Elvis Presley can iteratively experiment through performing and listening to playback, ${ }^{131}$ thus expanding the role of deliberation in performance.

The etiology approach is particularly difficult to apply to contemporary non-veridic sound recordings, because they typically are constructed in dense layers of composition and performance, if we take composition to include the deliberate activities of selecting recorded passages, mixing them, altering them through processing, and so on. ${ }^{132}$ It will often be very difficult even to reconstruct, in an era of sophisticated digital music production software and hardware, whether any particular feature stemmed from performance or deliberative processing. It may be that when Robert Johnson sings the first syllable of the word "hearted" in his recording of "Drunken Hearted Man" ${ }^{133} 10$ cents lower than a true G sharp, he is doing so spontaneously in performance - although it is possible that even there, our desire to hear Johnson as an authentic, unselfconscious figure may deafen us to the possibility that he engaged in more deliberation than meets the ear. ${ }^{134}$ Moving forward about 70 years, the background vocals in Rihanna's recording of "S.O.S." 135 are also microtonally off pitch - the right channel vocals are raised by 9 cents, and the left channel lowered by 9 cents - and they are also between 13 and 19 milliseconds behind the beat. That, however, is the work of Phil Tan, the mix engineer for "S.O.S.," who electronically adjusted the vocals after recording, and presumably after having experimented with several

Collaborative models, interactive methods, and music digital library tool development, 59 J. Am. Soc. for Info. Sci. \& Tech. 1878 (2008).

${ }^{131}$ See supra TAN xxx.

${ }^{132}$ For further description of this layering, see TAN xx, supra.

${ }^{133} \mathrm{See}$ http://www.youtube.com/watch?v=hbwLznhwIQ8.

${ }^{134}$ There is a tantalizing hint that Johnson or the record company that released his records may have been interested, not just in faithfully capturing his performance, but in creating a recorded sound experience that does not exist in the real world. Some have argued that the recordings were sped up by $20 \%$ or more before release, perhaps intentionally to make the playing and singing faster than it was in real life. See Jon Wilde, Robert Johnson revelation tells us to put brakes on the blues, The Guardian, $\begin{array}{llll}\text { Music Blog, } & \text { May 2010, }\end{array}$ http://www.guardian.co.uk/music/musicblog/2010/may/27/robert-johnson-blues ("Either the recordings were accidentally speeded up when first committed to 78, or else they were deliberately speeded up to make them sound more exciting. Whatever, the common consensus among musicologists is that we've been listening to Johnson at least $20 \%$ too fast.").

${ }^{135}$ See http://www.youtube.com/watch?v=IXmF4GbA86E. 
options before settling on just those levels of pitch alteration and delay. ${ }^{136}$ The "S.O.S." example also shows how the etiology approach could diverge from the micro/macro approach, since 9 cents and 13 milliseconds are presumably "micro" features, and from the music analysis approach, since there are no major harmonic or rhythmic changes implicated.

\section{The Macro/Micro Approach.}

The micro/macro approach takes the position that all nuances that occur within individual notes, such as overtones and changes over note envelopes, are not part of musical works, which consist only of larger-scale structures of melody, harmony, and rhythm. This approach seems to be an important driver in the decisions of the courts in Newton $v$. Diamond ${ }^{137}$ and Poindexter v. EMI Record Group, ${ }^{138}$ which filter out timbral detail before concluding that the "notes," stripped of detail, are not sufficiently complex to be protected by copyright law. Those examples suggest that courts often see the micro/macro approach as aligned with the notation approach, on the assumption that traditional Western staff notation contains nothing other than notes, and therefore has nothing to say about smaller-scale details. Although it is true that Western staff notation may emphasize larger scale structures, I have tried to show above that Western staff notation can include plenty of directions that are intended to influence smaller-scale details, and that the alignment between those two approaches is therefore far from perfect.

The intuitive appeal of the macro/micro approach may be attributed in part to the perception that small-scale details are produced spontaneously in performance, and do not need copyright protection because they cannot be perfectly copied by others: no other vocalist can become Luciano Pavarotti or Adele Adkins. As sound technologies improve, however, small-scale details in recordings become easier to manipulate independent of performance, as the "S.O.S." example above demonstrates. Another part of the intuitive appeal of this approach may be connected to the opinion that copyright should be concerned with protecting works - larger-scale, coherent assemblages - rather than small-scale details. That view, however, does not necessarily justify excluding small-scale details from consideration as components of those assemblages, any more than we would say that, because individual notes are

\footnotetext{
136 See "Secrets of the Mix Engineers: Phil Tan," http://www.soundonsound.com/sos/feb07/articles/insidetrack_0207.htm. 137349 F.3d 591 ( $9^{\text {th }}$ Cir. 2003).

${ }^{138} 2012$ WL 1027639 (S.D.N.Y.).
} 
not protected, we should remove every note from a notated composition before conducting infringement analysis.

\section{The Music Analysis Approach.}

Music analysis, and tonal analysis in particular, presumes that all notes in a musical composition can be hierarchically ordered in relation to a melodic and harmonic structure that is grounded on a tonal center - one note that is the center and point of repose for the entire composition. Most popular music can be classified as tonal, and thus is susceptible of tonal analysis. Rhythm can also feature in musical analysis, with accented beats counted as higher up in the hierarchy then unaccented beats. One can see applications of such analytical methods - whether they are good applications or not - in expert testimony in infringement cases. For example, in Swirsky, Swirsky's expert testifies that "notes falling on the beat will be more prominent to the ear than notes falling off the beat," notes that differed between the recordings at issue should be discounted because they were off the beat. Perhaps such analysis is useful in some circumstances, but it should be viewed warily, because, as Aaron Keyt has noted, it has the same structure as Learned Hand's abstractions test: "at each level of analysis, more notes are excluded as ornamental, until at the highest level only a short, abstract pitch structure remains." ${ }^{140}$ It is, then, a technique for granting broader protection to a work, and at the highest level clearly represents overbroad protection.

For present purposes, it is equally important to understand that musical analysis has not traditionally been used to distinguish composition from performance. Indeed, it developed as a technique to analyze notated musical compositions, and to identify which of the notes were ornaments that did not contribute to the basic structure of the work, and which were more integrally connected with larger scale structures. Thus, whether a particular feature of a musical work is "ornamental" or "structural" has nothing to do with whether it is composition or performance, either in the sense of whether it is notated or whether it is the result of deliberation. One can easily spontaneously improvise a melody or chord sequences that establishes a tonal center, decisively moves away from it, and just as decisively moves back again.

C. A Recap and Summary

\footnotetext{
${ }^{139}$ Swirsky v. Carey, 376 F.3d at 841.

${ }^{140}$ Aaron Keyt, An Improved Framework for Music Plagiarism Litigation, 76 Cal. L. Rev. at 437 (1988).
} 
The aim of this analysis has been to cast serious doubt on the assumption that there is any easy way to determine which features of a phonorecord-embodied musical work count as "composition" and which count as "performance." At least four different approaches seem to appear in expert testimony and judicial discussion. When they all point in the same direction, it may seem as though the distinction between composition and performance is solid and elemental. Upon closer inspection, the ease and simplicity disappear, and the application of the tests to sound recordings seem inappropriate, practically impossible, or both.

As a matter of statutory interpretation, these difficulties should lead to a consideration of whether the 1976 Act, in recognizing copyright in phonorecord-fixed musical works, by implication mandated reinterpretation of the provision in the Sound Recording Act of 1971 that copyright "do[es] not extend to the making or duplication of another sound recording that consists entirely of an independent fixation of other sounds." ${ }^{141}$ That provision may have originally been thought to mandate recognition of a category of performance elements in sound recordings that would not be protected as part of the musical works embodied in those sound recordings. ${ }^{142}$ Yet that interpretation was formed at a time when only notated musical works were recognized as subject to copyright protection. This Part has concluded that the recognition of phonorecord-fixed musical works has left us without a single appropriate approach to isolate composition elements from performance elements. As a matter of policy, that conclusion leads to a more thorough consideration, in the next Part of this Article, of the merits, drawbacks, and practical consequences of discarding the composition/performance distinction.

\section{A GLIMPSE INTO THE WORLD OF THE INCLUSIVE PHONORECORD-EMBEDDED MUSICAL WORK: BENEFITS, DRAWBACKS, AND CONSEQUENCES}

What would the world of music copyright look like if we were to treat musical works fixed in phonorecords as extending to every aspect of recorded sound, thus discarding the composition/performance distinction, and treating such a musical work as coextensive with the sound recording?

${ }^{141}$ Sound Recording Act of 1971, supra note 1, \$ 1(a) (codified at 17 U.S.C. \$ 1(f) (1909)).

${ }^{142}$ The required reinterpretation is not of the same difficulty or gravity as a repeal by implication. Even if copyright in phonorecord-fixed musical works was coextensive with copyright in the sound recordings fixed in those phonorecords, $\$ 114(\mathrm{~b})$ would still have work to do: its limitation would still apply to sound recordings that are not also musical works, such as recordings of ambient sounds and spoken word recordings. 
This Part takes a first crack at addressing that question. In particular, it considers matters of infringement analysis, authorship, and licensing. It will argue that an inclusive approach to phonorecord-embedded musical works has potential benefits in all three of those areas. An inclusive infringement analysis will better implement the traditional holding that similarity of musical works is to be assessed by listening, and with the reality that listening experiences are concrete and detailed, and that many different elements of those experiences can affect perceptions of aesthetic similarity. An inclusive approach is also more likely to acknowledge authorship on the part of those who contribute a variety of different elements that give musical recordings aesthetic appeal. Finally, an inclusive approach removes an obstacle to recognizing unified copyright in some phonorecord-embedded musical works.

\section{A. Inclusive Infringement Analysis}

When considering the issue of whether one musical work infringes another, courts have frequently noted that music is fundamentally an aural experience, and that one has engage in acts of listening to determine whether two musical works are substantially similar. A long tradition of decisions recognizing that substantial similarity in music is to be judged through listening ${ }^{143}$ culminates in Judge Jerome Frank's classic formulation in Arnstein v. Porter: "The question ... is whether defendant took from plaintiff's works so much of what is pleasing to the ears of lay listeners, who comprise the audience for whom ... popular music is composed, that defendant wrongfully appropriated something which belongs to the plaintiff." 144

It seems, moreover, that our identification of musical experiences as similar or dissimilar and as pleasing or displeasing takes into account all aspects of those experiences, though some may predominate in particular cases. For example, an important set of experiments conducted by Prof. Jamie Lund suggest that listener perceptions of similarity of what she classifies as the "compositional elements" of melody, harmony and rhythm are significantly

${ }^{143}$ See D'Almaine v. Boosey, 1 Y. \& C. 288, 302160 Eng. Rep. 117, 123 (Ex. 1835) ("Substantially the piracy is where the appropriated music, though adapted to a different purpose from that of the original, may still be recognised by the ear."); Jollie $v$. Jaques, 13 F.Cas. 910, 914 (1850) (infringement depends upon whether "the ear detects the same air in the new arrangement"); Austin v. Columbia Gramophone Co. [1917-23] Macg. Cop. Cas. 398. Cf. Hyperion Records v. Lionel Sawkins, [2005] 3 All ER 636 (CA) ("The test of substantial reproduction is not a note-by-note textual comparison of the scores. It involves listening to and comparing the sounds of the copyright work and of the infringing work.").

${ }^{144}$ Arnstein v. Porter, 154 F.2d 464, 473 (2d Cir. 1946). 
affected by varying the "performance elements" of tempo, key signature, orchestration and style, ${ }^{145}$ because listeners do not naturally perceive those elements separately, but hear the mixture of all elements as a whole. Similarly, Aaron Keyt has argued that our musical perception is holistic - that, in his terms, "we, as musical listeners, tend not to hear merely acoustical sounds per se, but rather structural relations among sounds[, and a] change in any element can alter these structural relations." ${ }^{146}$ Keyt uses an example similar to Lund's experimental samples, in which he asks the reader to compare a passage from Scott Joplin's "The Entertainer" to a passage that he himself composed (and titled "The Plagiarizer"). In Keyt's example, however, he uses much of the melodic line of the Joplin passage, but changes rhythm and harmony. "No listener," he asserts, "is likely to find these two musical phrases identical, nor even particularly similar." 147 Recall, as well, that a number of scholars have argued that our listening experiences of recordings in particular are likely to involve aesthetically significant discoveries, not just of large-scale structures of tonal harmony, but also of timbres and textures, since they can emerge as important upon repeated relistening. Thus, in cases alleging infringement of a phonorecord-embodied musical work, one should base substantial similarity analysis on listening to a rendering of the allegedly infringed phonorecord as a whole, and one should do the same in cases alleging infringement by a phonorecord-embodied work.

That may sound good in principle, but in practice, how would an inclusive view of phonorecord-fixed musical works affect how copyright infringement analysis is conducted, both in the absence and presence of related notated musical works? Here's an example, drawn from the facts of litigation between Les Baxter and John Williams. Baxter sued Williams and related parties, claiming that the main theme from the motion picture "E.T., the Extra-Terrestrial," 148 composed by Williams, infringed Baxter's song "Joy," part of a suite of songs entitled "The Passions." ${ }^{\text {"49 }}$ Baxter composed the suite in

${ }^{145}$ See Jamie Lund, An Empirical Examination of the Lay Listener Test in Music Composition Copyright Infringement, 11 Va. Sports \& Ent. L. J. 117, 146-147 (2011).

${ }^{146}$ Aaron Keyt, An Improved Framework for Music Plagiarism Litigation, 76 Cal. L. Rev. 421, 434 (1988) (emphasis in original).

${ }^{147}$ Id. Keyt's article only presents the two works in staff notation, but I have made simple rendered-midi-file recordings of his notations that are available at http://www.law.gwu.edu/facweb/rbrauneis/musicalworkcopyright.htm.

148 A recording of that theme can be heard at "E.T. Movie Theme - full - HQ," http://www.youtube.com/watch?v=QPhElXZXw3s .

${ }^{149}$ Reported opinions in this litigation include Baxter v. MCA, Inc., 812 F.2d 421 ( $9^{\text {th }}$ Cir. 1987), cert. denied, Williams v. Baxter, 484 U.S. 954 (1987); Baxter v. MCA, Inc., 907 F.2d 154 ( $9^{\text {th }}$ Cir. 1990). 
1953, and released a recording of it in 1954, as performed by an orchestra he conducted and vocalist Bas Sheba. Neither "Joy" nor any of the other songs that comprised "The Passions" were ever published in the form of scores or sheet music. Thus, to obtain federal copyright protection for "Joy" as a musical work, Baxter's music publisher, Beechwood Music Corp., registered it as an unpublished musical composition. ${ }^{150}$ The recording of "The Passions" released under Baxter's name in 1954 was, as far as I have been able to tell, the only recording of the work ever published. ${ }^{151}$

During the course of the litigation, the parties clashed over whether a synthesized version of Baxter's score should be played to the jury, in addition to the 1954 recording. Williams contended that it should be excluded. He argued that Baxter had increased the articulation and relative volume of one sequence of notes in the synthesized version to make it more prominent and thus to increase the perception of similarity between "Joy" and the "E.T. Theme." 152 Baxter replied that the lack of articulation and low volume of the sequence in the 1954 recording was due to the inferior recording technology at the time, and that the synthesized version more accurately reflected the Baxter's work - i.e., apparently, the score. ${ }^{153}$

Consider, first, a hypothetical alteration of these facts, in which "Joy" had never been notated, and therefore in which the only embodiment of the musical work was the recording or phonorecord published in 1954. In that case, under the inclusive or coextensive view of phonorecord-embodied musical works, it should clearly be error to submit to the jury (or to the judge sitting as fact-finder) a revised, synthesized version of the work in which the articulation and relative volume of musical lines were altered. It is simply part of the musical work embedded in the recording that a particular musical line is in the background, indistinct, and of low volume. Those characteristics of

${ }^{150}$ See U.S. Copyright Registration Eu 347744 (February 15, 1954) (“Joy,” music by Les Baxter, $\odot$ Beechwood Music Corp.); supra note 22 (explaining federal copyright protection for registered, unpublished musical works under the Copyright Act of 1909). Although the compositions in the suite "The Passions" were all songs, in the sense that they featured vocalists, the vocalists sang only nonsense syllables like "La" and "Aw," and so the compositions did not include lyrics.

${ }^{151}$ See Les Baxter, "Les Baxter conducts his original musical composition The Passions, featuring Bas Sheba" (Capitol Records 1954). The recording can be heard at "Les Baxter - The Passions - Joy," http://www.youtube.com/watch?v=LTwUTFmGXIQ.

${ }^{152}$ See M. Fletcher Reynolds, "Music Analysis for Expert Testimony in Copyright Infringement Litigation" 190-191 (Doctoral Dissertation, University of Kansas, 1991) (University Microfilms, Inc. Order Number 9210107) (discussing this controversy in the Baxter litigation with references to the record in the case).

${ }^{153}$ See id. 
that sequence of notes might well be important to a jury finding that the line played a minimal role in the appeal of "Joy," and that even if John Williams had copied that particular sequence of notes, he had placed it in a very different context in the "E.T." theme, thus rendering the works substantially dissimilar.

Now consider the actual facts of the "Joy" case. They are more complicated, because they involve both a notated musical work and a musical audio work, and thus Baxter can sue for the infringement of the notated work as well. (Assume for the moment that Baxter owns copyright in both works, an issue we'll consider further below.) Of course, the notated work should be considered as a whole as well. The score of "Joy" included notes that specified that the musical line in question was to be played "piano," i.e., quietly, and that it should be played on a xylophone, with soft hammers. ${ }^{154}$ Thus, a synthesized performance of the score in which the musical line was played forte by synthetic trumpets would clearly not accurately represent the work.

In addition, the fact that the notated musical work never had any independent commercial value - that scores were never published or sold ${ }^{155}$-should be taken into account in the copyright infringement case. Thus, if a jury were to find infringement of the score but not the recording, Baxter should not able to recover any actual damages, though he presumably could recover statutory damages, and might conceivably be able to recover some portion of the profits generated by the "E.T." theme. The lack of commercial publication of the score up through the infringement litigation, over thirty years after the score was composed, might also on a plausible reading of the Supreme Court's decision in eBay Inc. v. MercExchange, L.L.C. ${ }^{156}$ be relevant to whether injunctive relief was available, on the theory that the failure to grant an injunction to Baxter might not cause him an irreparable injury, since he had never marketed the score nor had any plans to do so. In any event, the economic center of the litigation is the recorded version of "The Passions," which was released commercially, and even today is available on Compact Disc. The musical work embodied in that recording is different than the notated score, and should be considered on its own terms. ${ }^{157}$

${ }^{154}$ See M. Fletcher Reynolds, supra note 133, at 190-191.

155 There may be someone at Bax Music, Inc., "Home of the Les Baxter catalogue," who would inform me that there have other sales, rentals, or public performances of the scores. See http://www.baxmusic.com/.

156547 U.S. 388 (2006).

${ }^{157}$ Recall that it seems to be the case that musical works fixed in phonorecords before the effective date of the Copyright Act of 1976 (January 1, 1978), as well as before the 
Three subsidiary issues may arise in connection with infringement cases under an inclusive view of phonorecord-embedded musical works. Two of those are the important procedural issues of when summary judgment would be available and when expert testimony would be admitted, and I discuss those in an online note. ${ }^{158}$ The third is the threshold boundary issue of whether a particular phonorecord contains a musical work at all. After all, spoken-word sound recordings and ambient sound recordings also include sounds with overtones and attack-sustain-decay-release envelopes, so do they also qualify as musical works? Here it may be that the "melody, harmony, and rhythm" definition has a role to play. A sound recording that contains no discernible sequences of pitches, or concurrently sounded pitches, or accented pulses, may not be something that we are prepared to call a musical work. Yet to say that sounds without any of these aspects don't count as music is not to say that only these aspects count as music. Every pitch sounded will either have overtones or it won't. Every pitch will also either start suddenly, remain absolutely uniform throughout its duration, and end just as suddenly, or it will change in various ways as it sounds. Either way, such characteristics are important to our experience of music, just as the pitch itself is, and they have become even more important in the age of recorded music.

\section{B. Authorship, Ownership and Public Performance Rights}

What implications would an inclusive view of musical audio works have for issues of authorship and ownership? One might think that the implications would be drastic, yet given current copyright law provisions concerning joint authorship and compulsory licensing, they would seem to be relatively modest for existing recordings, and would open up more room for bargaining with regard to future initial recordings.

\section{Joint Authorship}

effective date of the Sound Recording Act of 1971 (February 15, 1972) are now eligible for copyright. See supra note 95. The Baxter court holds that Baxter's claim rests solely on his registered sheet music, since the sound recording was made before federal copyright law protection extended to sound recordings. See Baxter v. MCA, 812 F.2d at 422 n. 1. This statement may reflect the Ninth Circuit rule at the time of this decision that sound recordings effected a divestive publication of the musical works contained in them. However, Congress legislatively overturned that rule, see supra note 23, and hence the musical work embedded in the 1954 sound recording of "Joy" is eligible for copyright.

${ }^{158}$ See

http://docs.law.gwu.edu/facweb/rbrauneis/musicalworkcopyright/summaryjudgment experttestimony.htm. 
The song "Good Vibrations," released as a single in 1966 by the Beach Boys, is credited in the BMI repertoire to Brian Wilson and Mike Love. According to Philip Lambert, Wilson did not compose the song as a Tin Pan Alley songwriter would have, conceiving of the final product as sheet music that would be sold to be performed by others. Rather, from the beginning, he conceived of "Good Vibrations" as an audio work, and worked for months on creating just the sequence of sounds he wanted. He approached more than one person about writing words for the song, but among them was Mike Love, whose words became part of the song in its canonical recorded version. Wilson also used about twenty musicians to record various performances in four different recording studios. The result was 90 hours of sound on magnetic tape, which Wilson edited and mixed to create the final three minute and thirty-five second record. ${ }^{159}$ Whether we use the "double intent" test of the Second and Seventh Circuits, ${ }^{160}$ or the "control" or "superintendence" test of the Ninth Circuit, ${ }^{161}$ it seems clear that not all twenty musicians were joint authors of the song as an inclusive audio work, even if they all made musically significant contributions to it. Yet under either of those tests, it is quite likely that Wilson and Love would be found to be joint authors, since Wilson apparently ceded control over the lyrics to Love, and they both intended to merge their contributions into a single work. Thus, an inclusive view of musical audio works would often not change determinations of authorship.

Sometimes, however, it would. Consider, for example, the creation of "The Reasons Why," the work that was allegedly infringed by Usher Raymond's "Burn" in Straughter v. Raymond. ${ }^{162}$ Given the facts related by Judge Snyder in her opinion in that case, it seems likely that the song was never fixed in notated or recorded form before it was recorded by the band "Reel Tight." The first fixation, in a sound recording, was probably assembled over hours or days of experimentation by the four band members and six others who are credited for various contributions to the recording, including plaintiff Ernest Straughter, who was not a band member but was in the studio with the band during a recording session. ${ }^{163}$ The only published version of that

${ }^{159}$ See Philip Lambert, Inside the Music of Brian Wilson: The Songs, Sounds, and Influences of the Beach Boys' Founding Genius (2007).

${ }^{160}$ See Childress v. Taylor, 945 F.2d 500; Erickson v. Trinity Theatre, 13 F.3d 1061 ( $7^{\text {th }}$ Cir. 1994); Thomson v. Larson, 147 F.3d 195 (2d Cir. 1998).

${ }^{161}$ See Aalmuhammed v. Lee, 202 F.ed 1227 (9 $9^{\text {th }}$ Cir. 2000).

1622011 WL 3651350 (C.D. Cal.).

${ }^{163}$ See Straughter, 2011 WL 3651350 at * ("Plaintiff claims that he began composing a song entitled "The Reasons Why" ("Reasons") in March or April 1998, and completed it in May 1998, during a break in one of his sessions with Reel Tight. . . According to plaintiff, when the members of Reel Tight returned to the studio from the break, they 
sound recording was released on Reel Tight's album "Back to the Real" under the title "No More Pain," and the album notes gave authorship credit for the song to all four band members, Straughter, and his brother David Straughter. ${ }^{164}$ Documents uncovered during litigation showed that Straughter has accepted a 13\% ownership interest in the song. ${ }^{165}$ Some months before the release of "Back to the Reel," Straughter registered a claim of copyright in "The Reasons Why" as an unpublished musical work, listing himself and his brother David as authors. ${ }^{166}$ The deposit accompanying the registration was a sound recording that apparently featured the creative contributions of all credited on the "Back to the Real" pamphlet - a recording was nearly identical to the version released on "Back to the Real."

Suppose that all band members agreed that Ernest and David Straughter had come up with the words and the basic melody for the song. Nonetheless, under the inclusive view of musical audio works, a court could be justified in finding that all band members were joint authors of the song in its only fixed form, as a phonorecord-fixed musical work. ${ }^{167}$ As words and a melody settled only in the minds of the Straughters, that work was hardly complete. The Reel Tight band members contributed harmonies, rhythms, vocal embellishments, and instrument timbres, and may well have determined the structure of the song (added an intro, a bridge, and an outro, and determined the number of times the melody would be repeated), and even modified the words and melody. The credit on the album notes, and the $13 \%$

heard him playing "Reasons" and wanted to record it, which they did."); Reel Tight, "Back to the Real" (1999) (those credited for "No More Pain" in the CD booklet include "Produced by: Reel Tight $\bullet$ Co-Produced by: Ernest Straughter \& David Straughter for Khamillion Entertainment $\bullet$ Written by: Bobby Torrence, Reginald Long, Danny Johnson, Robert Rice, Ernest Straughter, David Straughter $\bullet$ Arranged by: Reel Tight $\&$ Ernest Straughter for Khamillion Entertainment $\bullet$ Keyboards and Programming: Ernest Straugher $\bullet$ Drums \& Percussion: Bobby Torrence $\bullet$ Drum Programming: David Straughter $\bullet$ Acoustic \& Electric Guitar: James T. Macon $\bullet$ Bass: Bobby Watson $\bullet$ Engineered by Charles Nassar . . •Mixed by: Craig Burbidge")

${ }^{164}$ See supra note 157 for the credits for "No More Pain."

${ }^{165}$ Straughter, 2011 WL 3651350 at *4.

${ }^{166}$ See Straughter, 2011 WL 3651350 at *2. Ernest Straughter later asserted that he was the sole author of the song, and had only included his brother as a "goodwill gesture." See id.

167 For an English case that concluded, on somewhat similar facts, that authorship should be attributed to a single composer, see Hadley v. Kemp, [1999] EMLR 569. For critical reviews of this case, see Lionel Bently, Authorship of popular music in UK copyright law, 12 Information, Communication \& Society 179. 190-192 (2009); Anne Barron, Introduction: Harmony or Dissonance? Copyright Concepts and Musical Practice, 15 Social \& Legal Studies 25, 26-30 (2006). 
ownership interest assigned to Ernest Straughter, which he apparently accepted, are objective evidence of the intent of all involved to treat each other as co-owners. The authorship of "The Reasons Why" was only marginally at issue in Straughter v. Raymond; if the issue were more directly litigated, more evidence that affected a determination of authorship might emerge. The point here is that in principle, the authors of words and a melody might be found to share co-authorship of a musical audio work with others who contributed to it and who met the applicable joint authorship tests. ${ }^{168}$

\section{The Mechanical License.}

Since 1909, virtually all "cover versions" of musical works - recordings made after the initial publicly distributed recording - have been made under the statutory license in $\$ 1(\mathrm{e})$ of the 1909 Act or $\$ 115$ of the 1976 Act, or under a license issued by the Harry Fox Agency that incorporates the terms of that statutory license. Section 115 (b) of the 1976 Act explicitly provides that a statutory licensee can make an arrangement of the licensed musical work when recording it, but that the arrangement "shall not be subject to protection as a derivative work under this title, except with the express consent of the copyright owner."169 Note that this provision contemplates that at least some of what is added to a preexisting musical work when it is recorded could amount to a copyrightable "arrangement," and not just uncopyrightable "performance." In any event, however, it denies copyright protection to that arrangement unless the copyright owner expressly consents, something that in practice does not occur.

Under an inclusive view of musical audio works, the $\$ 115$ (b) default provision would act to deny copyright protection to every phonorecord-fixed musical work that was derivative of an earlier work and made under a statutory license of that earlier work. In other words, when Adele records a

${ }^{168}$ U.S. courts may be hesitant to assign unequal interests in the absence of agreement due to their lack of confidence in their aesthetic judgment. See Benjamin E. Jaffe, Rebutting the Equality Principle, 32 Cardozo L. Rev. 1549 (2011) (arguing that courts should recognize unequal contributions to copyrighted works). However, they might at least consider agreements to assign unequal shares, such as the agreement mentioned in Straughter v. Raymond concerning the ownership of "The Reasons Why" (or "No More Pain" in its released version), as evidence of the creators' own assessment of relative contributions, especially if the unequal distributions seem to have some parallel in the importance of the author's contributions to the finished work. Such an approach might facilitate findings of joint authorship within musical practices that clearly seem collaborative.

${ }_{69} 17$ U.S.C. $\$ 115(b)$. 
version of Bob Dylan's "Make You Feel My Love," 170 she creates under the inclusive view of musical works what otherwise would be a copyrightable derivative work. However, since that recording was almost certainly made under a Harry Fox license, neither she nor anyone else who contributed to that recording owns copyright in the musical work embedded in it. That means that when Adele's recording is publicly performed, no one has to pay Adele or her assignee for public performance of the derivative musical work she created. ${ }^{171}$ The legal situation should be the same for cover recordings made under the 1909 Act. ${ }^{172}$ The advantage of that lack of copyright is that the recognition of musical audio works would upset fewer settled expectations; the disadvantage is that that recognition would do little for those who make creative contributions to recordings made under the compulsory mechanical license.

\section{Initial Recordings.}

That leaves the copyright status of initial recordings of musical works, which are not made under a statutory license. Musical works born as musical sound recordings do not present any particular problems. Authorship and initial ownership of such works would be determined by the rules of joint and sole authorship covered above; the statutory license under $\$ 115$ would grant permission to use such works for the purpose of making cover recordings, including permission to imitate any aspect of sound in the recording. Suppose, however, that in a traditional songwriter-recording artist arrangement, a songwriter produces a notated musical work, and grants a voluntary license to a recording artist to make an initial recording of that work. If the recording is considered to be a copyright-protected musical audio work, and not just a sound recording, could a recording artist then be owed royalties for the public performance of her recording of a notated song, in addition to the public performance royalties owed to the notated song's composer?

Given traditional contracting practices working against the background of $\$$ 103(a) the 1976 Act and $\$ 6$ of the 1909 Act, most musical audio works that are initial recordings of notated works are not under

${ }^{170}$ For the Adele version, see http://www.youtube.com/watch?v=Fnn9JlqqTE4.

${ }^{171}$ Of course, when the recording is performed as a digital audio transmission, the owner of copyright in the sound recording may have to give permission or be compensated. See 17 U.S.C. \$S 106(6), 114(d).

${ }^{172}$ See the online note at

http://docs.law.gwu.edu/facweb/rbrauneis/musicalworkcopyright/1909actcompulsor ylicense.htm. 
copyright. It has long been accepted that permission to make a recording of a notated song does not necessarily include permission to create a derivative work. Thus, the \$115(b) provision denying copyright in arrangements produced under compulsory license without specific permission is a specific application of the more general provisions in \$103(a) of the 1976 Act and $\$ 6$ of the 1909 Act that deny copyright to any derivative work produced without permission. The issue of whether derivative musical works could gain copyright protection would have arisen under the 1909 Act as well. In the course of preparing a recording of a notated song, a recording artist might well notate a complex orchestral arrangement, and add sections to the song - an introduction, a bridge, a closing section - that did not exist in the notated work that she licensed. Apparently, the tradition has been for owners of copyright in notated songs to withhold permission to create such works from creators of initial recordings. ${ }^{173}$ To be sure, contracting parties in the music industry were very unlikely to have been thinking about the precise issue posed here, because musical works fixed only in phonorecords before 1978 were not subject to copyright protection, and the inclusive view of musical works advocated in the article was probably not within their imagination. Nonetheless, the fact that they almost always withheld permission to publish derivative musical arrangements provides good grounds for a presumption that they would not have permitted recording artists to claim derivative work copyright in musical audio works. ${ }^{174}$

The ability for songwriters and recording artists to bargain openly about public performance rights in initial recordings could have the advantage of greatly diminishing the apparently widespread practice of granting songwriting credit to recording artists. At least since the days of Al Jolson, recording artists have bargained for and received credit for co-writing notated works that they actually played no part in composing. ${ }^{175}$ This practice is

${ }^{173}$ It is very difficult to find copies of licenses to make initial recordings - they are generally not recorded at the Copyright Office, and are kept in private company archives. M. William Krasilovsky and Sydney Shemel state that "[t]he author of an arrangement cannot claim a derivative copyright in the arrangement without the consent of the copyright owner. Such consents are rarely given." M. William Krasilovsky and Sydney Shemel, This Business of Music 154 (9 $9^{\text {th }}$ ed. 2003). However, in context, this statement appears to be about compulsory licenses under $₫ 115$, not about initial recording licenses.

${ }^{174}$ The use of $₫ 103(\mathrm{a})$, not to deny copyright to infringing strangers, but to allow an owner of copyright to deny copyright to derivative works created within a contracting relationship, deserves further scrutiny, and perhaps abolition, but that topic is not within the scope of this article.

${ }^{175}$ See Geoffrey P. Hull, Termination Rights and the Real Songwriters, 7 Vanderbilt J. of Ent. \& Tech. Law 301, 301 (2005). 
evidence that what recording artists add to a notated song is so important to the success of the recording that songwriters are willing to give recording artists part of the streams of public performance and mechanical income that accrue only to composers. Though it is rarely acknowledged, the practice apparently continues to be widespread among top recording artists. For example, in an interview that was later removed from the website on which it was originally published, but is still quoted on third-party websites, songwriter Heather Bright claimed that Justin Bieber played no part in writing the song "Somebody to Love," for which he is credited and receives publishing income, ${ }^{176}$ and that other recording artists such as Rihanna and Kanye West bargained for and received credit for songs that they did not write. ${ }^{177}$

It if were acknowledged that musical audio works could be authorized derivatives of notated musical works deserving of public performance income, Justin Bieber could receive permission to create and be recognized as co-author of the musical audio work "Somebody to Love," and legitimately receive income from public performances of that work, without being falsely credited for co-authoring the notated work.

\section{Looking Towards the Future: Unitary Copyright in Musical Audio Works?}

So far, this Article has paid little attention to the copyright in sound recordings that exists parallel to and concurrently with the copyright that may be recognized in musical works embedded in those sound recordings. However, the relationship between those two layers of copyright deserves

${ }^{176}$ In the BMI repertoire database, the song, listed as BMI Work $\$ 11610494$, is credited to Justin Bieber, Heather Dawn Bright, Jeremy L. Reeves, Ray Romulus, and Jonathan James Yip. See BMI Repertoire, http://repertoire.bmi.com/startpage.asp (search for "Somebody to Love"). It is unclear whether Heather Bright was claiming sole authorship of the notated song, or whether she would recognize some of the other listed songwriters as co-authors.

177 See The Prophet Blog, "Hit Songwriter Heather Bright Exposes Top Pop Stars for Faking Writing Credits," http://www.theprophetblog.net/hit-songwriter-heatherbright-exposes-top-pop-stars-for-faking-writing-credits/; Carter Maness, "Songwriter Blasts Rihanna, Kanye Over Song Publishing," The Boombox, April 6, 2011, http:/www.theboombox.com/2011/04/06/songwriter-blasts-rihanna-kanyeover-song-publishing/. For other anecdotes about recording artists receiving credit for songs they did not write, see Peter Cooper, "On Music Row, is the Co-Write King?," http://blogs.tennessean.com/tunein/2010/03/19/on-music-row-is-the-co-writeking/ ; Occasional Hope, "When is a Singer-Songwriter Not Really a SingerSongwriter?," http://mykindofcountry.wordpress.com/2010/03/26/when-is-a-singersongwriter-not-really-a-singer-songwriter/ 
some scrutiny. Before the Copyright Act of 1976, the dominant explanation of their relationship drew on the composition/performance distinction. Musical compositions were works of written notation, and thus copyright in musical compositions covered what was expressed in that notation. Sound recordings, when they concerned music at all, captured performances of notated musical works. Copyright in a musical composition was almost always owned by a different entity than copyright in a sound recording of that musical composition. If, however, the 1976 Act were to be read as recognizing inclusive musical work copyright in a musical audio work, which included every element of sound fixed in a phonorecord, why would it make sense to continue to recognize separate sound recording copyright for the same sounds fixed in the same phonorecord?

One possible source of distinction is suggested by the Sixth Circuit's decision in Bridgeport Music, Inc. v. Dimension Films, ${ }^{178}$ which holds that the act of sampling a sound recording in another sound recording is always copyright infringement, or in other words, that there is no de minimis exception or substantial similarity analysis in sampling cases. ${ }^{179}$ If we were to adopt that rule, we could say that sound recording and musical work rights are distinguished by mode of copying. Sound recording rights are special rights concerning copying by electronic or mechanical processes such as sampling or dubbing, and are absolute bans on the use of such means. By contrast, musical work rights are rights against the creation of substantially similar works by any form of copying, whether electronic, mechanical, or through imitation. A full evaluation of the Bridgeport Music rule is not within the scope of this article, but suffice it to say that the rule is controversial. No court outside of the Sixth Circuit has adopted it, and one Eleventh Circuit District Court has specifically rejected it. ${ }^{180}$ If the rule is ultimately rejected, then we are again faced with the question of why a musical audio work should necessarily be subject to intrinsically divided copyright.

Though it may be difficult to think beyond traditional categories, in which we always speak of the "underlying musical work" as separate from the particular sound recording of that work, consider how unitary copyright is possible in audiovisual works, which join even more complex and disparate audible and visible elements. Putting aside the frequent use of the "works made for hire" provisions in the motion picture industry, which may obscure

\footnotetext{
${ }^{178} 410$ F.3d 792 (6 $6^{\text {th }}$ Cir. 2005).

${ }^{179}$ See id. at 800-801.

${ }^{180}$ See Saregama India Ltd. v. Mosley, 687 F. Supp.2d 1325, 1339-1341 (S.D. Fla. 2009), affirmed on other grounds, 635 F.3d 1284 (11 ${ }^{\text {th }}$ Cir. 2011).
} 
the analogy, consider a smaller-scale audiovisual project, in which four or five people decide to create a video. They agree in advance that their contributions will be merged together in a joint work, and that they will treat each other as joint authors. After they come to that agreement, one person writes some dialogue; another creates a set; a third appears as an actor; a fourth decides on camera angles and operates the camera.

The result of these varied contributions, the video, is covered by a single unitary audiovisual work copyright. We do not say that copyright in every motion picture must necessarily consist of an "underlying dramatic work" and an "audiovisual recording" based on that work. Of course, maybe we would be saying that if various copyright industries had successfully lobbied for different copyright law provisions. Suppose, for example, that dramatic publishers had joined with movie theater owners and television broadcasters to convince Congress to deny audiovisual works a public performance right. Perhaps the dramatic publishers would then be collecting fees for the public performance of an "underlying dramatic work" every time a movie was shown, and they would share that revenue with those identified as authors of that underlying dramatic work, but not with those who were identified merely as authors of the "audiovisual recording." Yet since that did not happen, we are not accustomed to dividing up motion pictures in that way, and it does not seem to us that there is anything in the nature of motion pictures that requires such a division.

The advantages of unitary copyright in works of authorship seem obvious. Although in some cases a work of authorship will be a derivative work, requiring two different licenses to use the work, in many cases it will not, and only one license will be needed. The savings in the transaction costs of bargaining for licenses should be substantial, as should the savings in the costs of maintaining two separate companies or associations to collect and distribute revenues to authors. To be sure, recognition of unitary copyright in musical audio works would necessitate a major realignment in the current dual industry structure of music publishing and recording, but that is not a reason to deny such recognition, unless one is approaching the issue from the perspective of an established member of one of those industries that is afraid of losing out in such a realignment.

Our lingering sense that all musical works have an essence independent of particular sound recordings of them may stem from the dominance of the model of literary works in copyright. Written language may not have gained complete independence from spoken language, but it has gained a great deal of independence. In the fourth century, St. Augustine was 
amazed to see St. Ambrose reading silently, without pronouncing the words aloud. ${ }^{181}$ These days, silent reading is a common practice, and we can learn new words and their meanings without knowing how they are pronounced not only are we not speaking aloud while reading, but we are not pronouncing the words to ourselves either. Because of that large degree of independence of written language from sound, it is relatively easy for us to conceive of literary works as independent of spoken performances of them.

Music has never gained the same degree of independence from sound. Even those who have developed the skill of sight-reading music to such an extent that they can read scores silently and "understand" them are engaging in an act of aural imagination, imagining what a performance of the score would sound like. They are not experiencing the "meaning" of the notes independently of any sound associated with them.

It is true, of course, that many songs originally conceived of and constructed as recordings have been covered by other artists. One might think that the existence of such covers is proof that the musical work has a life separate from the recording, and that by experiencing many such recordings and discarding the differences between them, we are able to arrive at a conception of the true musical work that underlies them all. Yet in truth there may just be a cluster of recordings that bear "family resemblances" 182 to each other, rather than a single, determinate, independent musical work that underlies them all, yet consists of only some subset of characteristics of the first recording, and not the sound in all its complexity.

Consider, for example, Queen's song "Bohemian Rhapsody."183 At about one minute and twenty seconds into that musical audio work, Freddie Mercury sings the line "But now I've gone and thrown it all away." When singing "all away," he changes to a much rougher voice, and the drums enter with a cymbal crash - a change in sound texture. When Jake Shimabukuro covers "Bohemian Rhapsody" on ukulele, his rendering contains a definite trace of that textural change; he strums the ukulele energetically, rather than

\footnotetext{
${ }^{181}$ See The Confessions of St. Augustine Book VI (translated by E.B. Pusey; Chatto and Windus edition 1921, etext prepared by Robert S. Munday), available at http://archive.org/stream/theconfessionsof03296gut/tcosal0.txt ("But when [Ambrose] was reading, his eye glided over the pages, and his heart searched out the sense, but his voice and tongue were at rest.")

${ }^{182}$ I borrow this term from Ludwig Wittgenstein, Philosophical Investigations $\$ 67$.

${ }^{183}$ Available at http://www.youtube.com/watch?v=fJ9rUzIMcZQ
} 
picking it delicately as he previously had been doing. ${ }^{184}$ In an a cappella recording by the UC Men's Octet, the lead singer sings with more pronounced vibrato then previously, and the accompanying singers switch from a covered "oo" to an open "aa, and back to "oo." 185 In the recording that Jonathan Groff makes with the cast of "Glee," the change of vocal texture moves earlier, to the word "Now" at the beginning of the line; ${ }^{186}$ that's also true of in the bluegrass semi-spoof version recorded by Hayseed Dixie. ${ }^{187}$ Adam Lambert, singing the song at an "American Idol" audition, decides to change texture and increase intensity even earlier, on the previous line "Life has just begun." 188 The point here is that it is virtually certain that all of these cover artists are familiar with the Queen recording, not a notated version, and are responding to and imitating features that appear in that recording, and sometimes modifying them. What we end up with is a cluster of similar musical audio works.

\section{CONCLUSION}

This article has argued that copyright law should approach issues of infringement analysis and authorship of musical works fixed in phonorecords without distinguishing between composition and performance elements. That distinction stems from a pre-sound-recording era in which musical works could be fixed only in scores, and performances were considered to be evanescent interpretations of those scores. Courts that depend upon such a distinction when analyzing musical audio recordings inconsistently apply four different approaches, none of which is particularly easy to apply or particularly appropriate. Approaching musical sound recordings without the composition/performance distinction could have three major advantages. First, such an approach would be more consistent with the basic understanding that substantial similarity in music is to be evaluated through the comparative aesthetic appeal of listening experiences. Second, it would help to enable creators of all aspects of those listening experiences to enjoy the incentives and benefits of authorship. Third, it could be a step towards recognition of unitary copyright in some musical audio works.

\footnotetext{
${ }^{184}$ Available at http://www.youtube.com/watch?v=PB3RbO7updc (the passage discussed in the text appears at about 2:20 - 2:24).

${ }^{185}$ Available at http://www.youtube.com/watch?v=UyqpjkCwEI4 (the passage discussed appears at about 1:30 - 1:38).

${ }^{186}$ Available at http://www.youtube.com/watch?v=VQHtAxluxnQ\&\&feature=fvsr (the passage discussed appears at about 1:15-1:20).

${ }^{87}$ Available at http://www.youtube.com/watch?v=sAW15peI8HY (the passage discussed appears at about 0:42-0:46).

${ }^{188}$ Available at http://www.youtube.com/watch?v=G9klVkwYkOk
} 
